\title{
Bowhead Whales, and Not Right Whales, Were the Primary Target of 16th- to 17th-Century Basque Whalers in the Western North Atlantic
}

\author{
B.A. McLEOD,${ }^{1,2}$ M.W. BROWN,${ }^{3}$ M.J. MOORE ${ }^{4}$ W. STEVENS,${ }^{5}$ S.H. BARKHAM, ${ }^{6}$ M. BARKHAM ${ }^{7}$ and B.N. WHITE ${ }^{1}$
}

(Received 9 March 2007; accepted in revised form 28 June 2007)

\begin{abstract}
During the 16th and 17th centuries, Basque whalers travelled annually to the Strait of Belle Isle and Gulf of St. Lawrence to hunt whales. The hunting that occurred during this period is of primary significance for the North Atlantic right whale, Eubalaena glacialis (Müller, 1776), because it has been interpreted as the largest human-induced reduction of the western North Atlantic population, with $12250-21000$ whales killed. It has been frequently reported that the Basques targeted two species in this region: the North Atlantic right whale and the bowhead whale, Balaena mysticetus L., 1758. To evaluate this hypothesis and the relative impact of this period of whaling on both species, we collected samples from 364 whale bones during a comprehensive search of Basque whaling ports from the 16th to the 17th century in the Strait of Belle Isle and Gulf of St. Lawrence. Bones were found and sampled at 10 of the 20 sites investigated. DNA was extracted from a subset $(n=218)$ of these samples. Analysis of the mitochondrial cytochrome $b$ region identified five whale species. The identification of only a single right whale bone and 203 bowhead whale bones from at least 72 individuals indicates that the bowhead whale was likely the principal target of the hunt. These results imply that this whaling had a much greater impact (in terms of numbers of whales removed) on the bowhead whale population than on the western North Atlantic right whale population.
\end{abstract}

Key words: Balaena mysticetus, Eubalaena glacialis, whaling, Basque, Little Ice Age, historical population size, DNA, bone, cytochrome $b$

RÉSUMÉ. Aux XVI et XVII e siècles, les baleiniers basques se rendaient tous les ans au détroit de Belle Isle et au golfe du SaintLaurent pour faire la chasse aux baleines. La chasse qui s'est effectuée pendant cette période revêt une grande importance pour la baleine franche ou baleine noire de l'Atlantique Nord, Eubalaena glacialis (Müller, 1776), car cette activité serait interprétée comme la plus grande réduction de la population de baleines franches de l'Atlantique Nord causée par l'être humain, au rythme d'environ 12250 à 21000 baleines tuées. On a souvent signalé que les Basques visaient deux espèces dans cette région, soit la baleine franche de l'Atlantique Nord et la baleine boréale, Balaena mysticetus L., 1758. Pour évaluer cette hypothèse et l'incidence relative de cette période de pêche aux baleines sur ces deux espèces, nous avons recueilli des échantillons provenant de 364 ossements de baleines dans le cadre d'une recherche approfondie de ports basques de chasse à la baleine remontant aux XVI ${ }^{\mathrm{e}}$ et XVII ${ }^{\mathrm{e}}$ siècles dans le détroit de Belle Isle et le golfe du Saint-Laurent. Des ossements ont été trouvés et échantillonnés à 10 des 20 sites ayant fait l'objet de notre recherche. De l'ADN a été extrait d'un sous-ensemble $(n=218)$ de ces échantillons. L'analyse mitochondriale cytochrome $b$ de la région a permis d'identifier cinq espèces de baleines. L'identification d'un seul os de baleine franche et de 203 os de baleines boréales provenant d'au moins 72 individus laisse croire que la baleine boréale était probablement la cible principale des chasseurs. Ces résultats impliquent que la chasse à la baleine a eu des incidences beaucoup plus grandes (en termes de nombres de baleines éliminées) sur la population de baleines boréales que sur la population de baleines franches de l'ouest de l'Atlantique Nord.

Mots clés : Balaena mysticetus, Eubalaena glacialis, chasse à la baleine, Basque, petit âge glaciaire, taille de la population historique, ADN, ossement, cytochrome $b$

Traduit pour la revue Arctic par Nicole Giguère.

\footnotetext{
${ }^{1}$ Natural Resources DNA Profiling and Forensic Centre, Trent University, DNA Building, 2140 East Bank Drive, Peterborough, Ontario K9J 7B8, Canada

${ }^{2}$ Corresponding author: brenna.mcleod@nrdpfc.ca or brennamcleod@trentu.ca

${ }^{3}$ New England Aquarium, Central Wharf, Boston, Massachusetts 02110, USA

${ }^{4}$ Woods Hole Oceanographic Institution, MS \#50, Woods Hole, Massachusetts 02543, USA

${ }^{5}$ Underwater Archaeology Service, Parks Canada Agency, 1800 Walkley Road, Ottawa, Ontario K1A 0L2, Canada

67 Chapel Street, Chichester, Sussex PO19 1BU, England

${ }^{7}$ Paseo de Galicia 5 (E-C) 20015, San Sebastian, Spain

(C) The Arctic Institute of North America
} 


\section{INTRODUCTION}

Historical tissue samples can be useful for assessing the population biology and past demography of threatened and endangered species. For many species, historical specimens are often not available for direct comparisons of genetic characteristics that existed prior to anthropogenic impacts with those of modern populations (Bouzat, 2001) and instead geographically distinct populations or sister species are used as surrogates (e.g., Palo et al., 2003). However, this reasoning by analogy can be inappropriate if the groups compared have differing demographic and phylogenetic histories. Analyses of historical specimens can provide information on historical levels of genetic diversity (e.g., Bouzat et al., 1998; Hadly et al., 1998; Groombridge et al., 2000; Matocq and Villablanca, 2001; Larson et al., 2002; Paxinos et al., 2002; Nyström et al., 2006); responses to climate change (e.g., Orlando et al., 2002; Barnosky et al., 2003; Hadly et al., 2003; Shapiro et al., 2004; Chan et al., 2005); systematics (Goldstein and Desalle, 2003; Krause et al., 2006; Poulakakis et al., 2006); rates of evolution (e.g., Lambert et al., 2002); bottleneck events (e.g., Hadly et al., 2003); and historical population dynamics (e.g., Leonard et al., 2000; Pertoldi et al., 2001; Barnes et al., 2002; Orlando et al., 2002; Shapiro et al., 2004). Many of these analyses have potential application in conservation genetics for species management, the evaluation of species recovery, and even the projection and prediction of biological responses to future environmental changes.

Whaling over the past five centuries represents one of the earliest and most detrimental human impacts on the marine ecosystem (Reeves and Smith, 2006). The industry was significant for its international distribution and participation and the "commercial extinction" of most large whale species. Not only did whale oil light the streets of Europe and America, fuel economies, and lubricate factories, but the industry left most large whale species endangered (Clapham et al., 1999) and may have affected food webs across hemispheres (e.g., Springer et al., 2003; but see Wade et al., 2007). Although the means to assess how whaling may have impacted large whale species are limited, it has been demonstrated that DNA can be successfully extracted from historical whale bones (Tebbutt et al., 2000; Rastogi et al., 2004; Morin et al., 2006; Borge et al., 2007), teeth (Pichler et al., 2001; Morin et al., 2006) and baleen specimens (Rosenbaum et al., 1997; Eastop and McEwing, 2004). This represents an important step towards using historical specimens to evaluate pre-exploitation levels of genetic diversity, population sizes, and catch composition.

The North Atlantic right whale (Eubalaena glacialis) and the bowhead whale (Balaena mysticetus) are two baleen whale species that have exhibited relatively limited recovery despite more than 70 years of international protection. The North Atlantic right whale is currently recognized as "endangered" (IUCN, 2006). Although it was once a trans-Atlantic species, the only viable population that remains is found primarily in the western North Atlantic (but see Knowlton et al., 1992; Martin and Walker, 1997; Reeves, 2001; Jacobsen et al., 2004) with 300-350 individuals remaining (IWC, 2001; Kraus et al., 2001, 2005 ). In addition to having a very small population size, this species has low genetic diversity (Schaeff et al., 1991, 1997; Malik et al., 2000; Waldick et al., 2002) and a low reproductive rate (Knowlton et al., 1994; Kraus et al., 2001), two factors that have been assumed to be a result of population reductions caused by whaling. The bowhead whale has 9000-14400 individuals remaining worldwide (Zeh et al., 1993; Moshenko et al., 2003; George et al., 2004), which are found within five designated stocks (Bering/Chukchi/Beaufort Sea, Okhotsk Sea, Hudson Bay/ Foxe Basin, Davis Strait/Baffin Bay, and Spitsbergen (Moore and Reeves, 1993; but see Heide-Jørgensen et al., 2006). However, $8100-13500$ (90-94\%) of these whales are found in the Bering/Chukchi/Beaufort Sea (George et al., 2004), and the status of recovery for the remaining four bowhead stocks has not been thoroughly evaluated. The Okhotsk Sea and Davis Strait/Baffin Bay stocks are currently recognized as "endangered," the Hudson Bay/Foxe Basin as "vulnerable," and the Spitsbergen stock as "critically endangered" (IUCN, 2006).

Sixteenth-century Basque whaling in the Strait of Belle Isle and Gulf of St. Lawrence represents the first directed commercial hunt of whales in the western North Atlantic. From approximately 1530 to 1630 , Basque whalers travelled annually from the Bay of Biscay to the Strait of Belle Isle, a narrow strait located between Newfoundland and Labrador, Canada, to hunt whales, primarily for their oil (Barkham, 1977, 1978，1984; Aguilar, 1986; Huxley [Barkham], 1987; Barkham, 1991). It has been suggested that 25000-40000 whales were killed during this time (Aguilar, 1986), encompassing both right and bowhead whales, and that each species comprised approximately half of the catch (Cumbaa, 1986). On the basis of this information, it was suggested that $\sim 12250-21000$ whales were removed from the historical population of right whales (Cumbaa, 1986; Gaskin, 1991). This is in comparison to subsequent whaling activities between 1634 and 1951 in the western North Atlantic, which are estimated to have taken at least 5500 right whales (and possibly double this number) (Reeves et al., 2007). Thus Basque whaling in the 16th and 17th centuries could represent the largest human-induced population reduction in the history of the western North Atlantic population of right whales (Gaskin, 1991) and possibly the species.

However, data from whale bones found at Red Bay, Labrador, a primary 16th-century whaling port, revealed a predominance of bowhead whales, a finding that brought into question the assumption that right whales were a principal target in this region (Rastogi et al., 2004). In contrast to Cumbaa's (1986) osteological analyses of 17 whale humeri from the 16th century, which suggested that right whales accounted for half of the Basque catch, Rastogi et al.'s (2004) genetic species identification using 


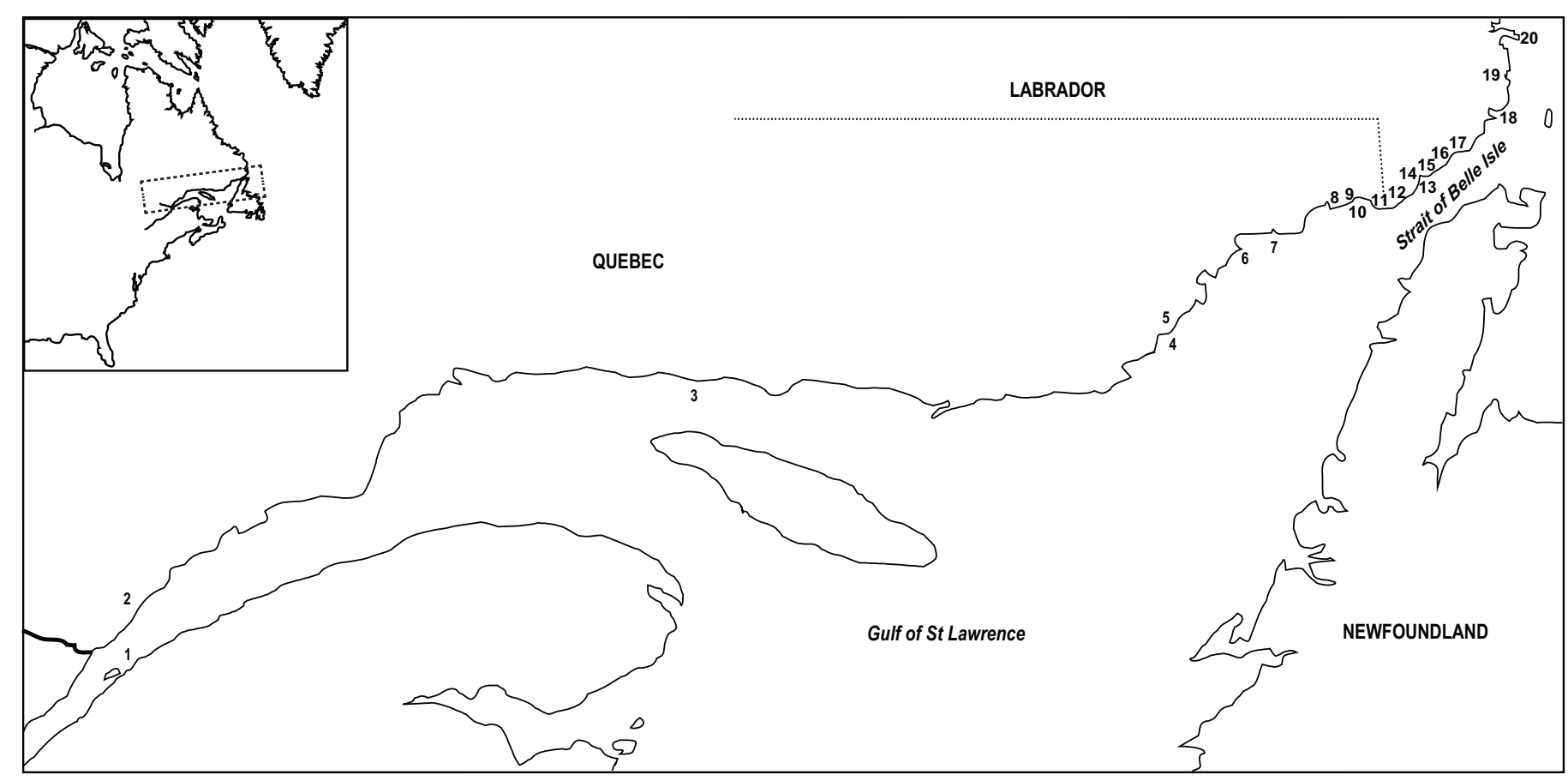

FIG. 1. Sixteenth-century Basque sites investigated in this study. Numbers 1-20 correspond to the sites indicated in Table 1.

sequence analysis of the mitochondrial cytochrome $b$ gene (including the same specimens assessed by Cumbaa, 1986) indicated that only one humerus was from a right whale, and 20 were from bowheads (5\% right, $95 \%$ bowhead). While these results suggested that the right whale represented a small proportion of the 16th-century catch in this region, and thus that bowheads may have been taken on a larger scale than has been recognized, the sample set was small and came from a single whaling site.

To evaluate which whale species were hunted by the Basques in the western North Atlantic and the relative involvement of each species, we have continued the analyses of Rastogi et al. (2004) with a larger sample set from a wider geographical distribution. This study expands the regional coverage to the major expanse of known Basque sites in southern Labrador and eastern Quebec, both in eastern Canada. We collected 364 samples from bones found at 10 of these sites for molecular species identification, including those analyzed previously by Cumbaa (1986) and Rastogi et al. (2004). This survey encompasses the majority of identified Basque whaling sites on the western North Atlantic seaboard, all of which are located on the north shore of the Strait of Belle Isle and Gulf of St. Lawrence and in the St. Lawrence River.

\section{METHODS}

\section{Site Identification and Sample Collection}

To identify 16 th- to 17 th-century Basque sites to include in this study and to locate terrestrial bone deposits within these sites, we consulted the available historical and archaeological literature (Table 1), archaeologists and historians (e.g., S.H. and M. Barkham; L. Turgeon; P. Drouin; W. Fitzhugh), and local townspeople. Extensive historical records suggest that all primary Basque whaling stations in northeastern North America during most of the 16th century were concentrated on the south coast of Labrador facing the Strait of Belle Isle, and that it was not until after about 1580 that Basques whaled west of Rivière St. Paul, Quebec, and thus west of the Strait of Belle Isle and into the Gulf of St. Lawrence (Fig. 1; Barkham, 1978). This expansion, however, occurred after the peak of Basque whaling in the region.

We investigated twenty 16 th- to 17 th-century coastal Basque sites located in Quebec and Labrador, Canada, for the presence of whale bones (Fig. 1, Table 1). This investigation involved walking along the coastline of each site and searching the soil surface (i.e., no excavation) for whale bones. Shores were searched from the water's edge to at least $10 \mathrm{~m}$ inland from the storm tide line. Samples were collected from identified bone specimens. In addition, samples were collected from underwater bone deposits in the harbour of Red Bay, Labrador, and from the collections of the Parc de l'aventure basque en Amérique (Trois-Pistoles, QC), the Whiteley Museum (Rivière St. Paul, QC), the Centre de Conservation du Québec (Quebec, QC) and the Red Bay National Historic Site of Parks Canada (Red Bay, NL).

A small area of each bone specimen was cleaned with a biological decontamination agent $\left(\operatorname{Decon}^{\circledR}\right)$ and $0.25-$ 0.5 -inch holes were drilled. Shavings from the outside of the bone were discarded to minimize microbial and other soil-associated contamination, and with a clean drill bit, $0.5-4 \mathrm{~g}$ of bone shavings were collected from the inner 
TABLE 1. Sites investigated in Quebec and Labrador, relevant references, number of samples collected and analyzed from each site, and minimum number of individuals represented from each site (MI). Samples collected from terrestrial and marine samples are designated as ' $\mathrm{T}$ ' and ' $\mathrm{M}$ ' respectively.

\begin{tabular}{|c|c|c|c|c|c|c|c|c|c|c|}
\hline \multirow{2}{*}{\multicolumn{2}{|c|}{ Contemporary Placename }} & \multirow{3}{*}{$\begin{array}{l}\text { Occupation } \\
\sim 1580-1650\end{array}$} & \multirow{3}{*}{$\begin{array}{l}\text { Reference } \\
\text { Lalande, 1991; Auger et al., 1992, 1993; } \\
\text { Fitzgerald et al., 1997; Turgeon, } 1998\end{array}$} & \multicolumn{2}{|c|}{$\underline{\text { Collected }}$} & \multirow[b]{2}{*}{ Total } & \multicolumn{2}{|c|}{ Analyzed } & \multirow[b]{2}{*}{ Total } & \multirow[b]{2}{*}{ MI } \\
\hline & & & & $\mathrm{T}$ & $\mathrm{M}$ & & $\mathrm{T}$ & $\mathrm{M}$ & & \\
\hline 1. & Île aux Basques, QC & & & 10 & 0 & 10 & 10 & 0 & 10 & 3 \\
\hline 2. & L'Anse à la Cave/Bon Désir, QC & early $1600 \mathrm{~s}$ & Lalande, 1989a, b, 1990; Turgeon, 1998 & 0 & 0 & 0 & 0 & 0 & 0 & \\
\hline 3. & Île Nue (Mingan Islands), QC & late 1500 s-early $1600 \mathrm{~s}$ & Barkham, 1978, 1984; Drouin, 1988; & 0 & 0 & 0 & 0 & 0 & 0 & \\
\hline 4. & Petit Mécatina, QC & late 1500 s-early $1700 \mathrm{~s}$ & $\begin{array}{l}\text { S. Barkham, pers. comm. 2000; } \\
\text { Fitzhugh, 2001; } \\
\text { Fitzhugh and Gallon, 2002; } \\
\text { Fitzhugh and Sharp, 2003; } \\
\text { Fitzhugh et al. 2004, } 2006\end{array}$ & 4 & 1 & 5 & 3 & 1 & 4 & 2 \\
\hline 5. & Havre Boulet, QC & late $1500 \mathrm{~s}-$ early $1600 \mathrm{~s}$ & Fitzhugh and Gallon, 2002 & 0 & 0 & 0 & 0 & 0 & 0 & \\
\hline 6. & Ile du Vieux Fort, QC & $\sim 1536-1632$ & Local reference & 0 & 0 & 0 & 0 & 0 & 0 & \\
\hline 7. & Île du Bonne Espérance, QC & $\sim 1536-1632$ & Huxley [Barkham], 1987; Local reference & 4 & 0 & 4 & 4 & 0 & 4 & 4 \\
\hline 8. & Five Leagues Harbour, QC & $\sim 1536-1632$ & $\begin{array}{l}\text { Huxley [Barkham], 1987; Niellon, 1986; } \\
\text { Niellon and McGain, } 1987\end{array}$ & 5 & 0 & 5 & 5 & 0 & 5 & 2 \\
\hline 9. & Middle Bay, QC & $\sim 1536-1632$ & $\begin{array}{l}\text { Barkham, 1977, 1980; Niellon, 1986; } \\
\text { Niellon and McGain, } 1987\end{array}$ & 10 & 0 & 10 & 10 & 0 & 10 & 5 \\
\hline 10. & Bradore Bay, QC & $\sim 1536-1632$ & S. Barkham, pers. comm. 2003 & 0 & 0 & 0 & 0 & 0 & 0 & \\
\hline & Blanc Sablon, QC & $\sim 1536-1632$ & Barkham, 1977, 1978 & 0 & 0 & 0 & 0 & 0 & 0 & \\
\hline & Schooner Cove, NL & $\sim 1536-1632$ & Barkham, 1977, 1978, 1980 & 0 & 0 & 0 & 0 & 0 & 0 & \\
\hline 13. & Capstan Island, NL & $\sim 1536-1632$ & Barkham, 1978 & 2 & 0 & 2 & 2 & 0 & 2 & 1 \\
\hline 14. & West St. Modeste, NL & $\sim 1536-1632$ & Barkham, 1978, 1984 & 1 & 0 & 1 & 1 & 0 & 1 & 1 \\
\hline 15. & $\begin{array}{l}\text { East St. Modest/ } \\
\text { Lily and Nelly Islands, NL }\end{array}$ & $\sim 1536-1632$ & Barkham, 1977, 1978, 1980 & 0 & 0 & 0 & 0 & 0 & 0 & \\
\hline 16. & Carrol Cove, NL & $\sim 1536-1632$ & Barkham, 1977, 1978, 1980 & 0 & 0 & 0 & 0 & 0 & 0 & \\
\hline & Red Bay, $\mathrm{NL}^{1}$ & $\sim 1536-1632$ & Barkham, 1977, 1978, 1980, 1984 & 55 & 172 & 227 & 42 & 99 & 141 & 42 \\
\hline & Chateau Bay/Henley Harbour, NL & $\sim 1536-1632$ & $\begin{array}{l}\text { Barkham, 1977, 1980, 1984; } \\
\text { Azkarate et al., } 1992\end{array}$ & 70 & 0 & 70 & 22 & 0 & 22 & 12 \\
\hline & Pleasure Harbour, NL & $\sim 1536-1632$ & Barkham, 1980 & 30 & 0 & 30 & 19 & 0 & 19 & 8 \\
\hline 20. & Cape Charles, NL & $\sim 1536-1632$ & $\begin{array}{l}\text { Huxley [Barkham], 1987; } \\
\text { Azkarate et al., 1992; Stopp, } 1997\end{array}$ & 0 & 0 & 0 & 0 & 0 & 0 & \\
\hline
\end{tabular}

${ }^{1}$ Includes Red Bay, Kelpy Cove, Steamer Cove, and Little Capstan Cove, NL.

core of each bone in a sterile weigh boat. Between each use, drill bits were soaked and cleaned with Decon ${ }^{\circledR}$ and then rinsed thoroughly with double-distilled water $\left(\mathrm{ddH}_{2} \mathrm{O}\right)$. While terrestrial bones yielded dry shavings, those from marine specimens were often wet and therefore required drying at $25-30^{\circ} \mathrm{C}$ for 12 to 24 hours immediately after sampling. All samples were then stored in plastic vials and placed in longterm storage at $-20^{\circ} \mathrm{C}$ upon return to the laboratory.

\section{Historical DNA Handling}

All sample handling prior to polymerase chain reaction (PCR) amplification was performed in a laboratory where genetic analyses with extant cetaceans have never been conducted. Therefore, all bone samples, reagents, and tools were physically isolated from any extant or PCRamplified whale DNA. Care was taken to minimize and monitor contamination by regularly cleaning and decontaminating the workspace and all tools and appliances with a $30 \%$ bleach solution or Decon ${ }^{\circledR}$ or both. Null samples (or "negatives") were included in each step of the DNA analysis (DNA extraction, amplification, PCR purification, and sequencing). These are tubes that are treated exactly as the regular samples are treated, but without the addition of DNA.

\section{DNA Extraction}

DNA was extracted from 150-300 mg of bone shavings as per Rastogi et al. (2004) using a modified version of the QIAamp ${ }^{\circledR}$ protocol for isolation for genomic DNA from compact bone (Qiagen, Mississauga, ON).

\section{Species Identification}

A 478 base pair (bp) region of the mitochondrial cytochrome $b$ gene of each sample was amplified using the oligonucleotide primers CBMYSTF1 (5'-CACATGGACTTCAACCATG-3') and CBMYSTR (5'-CCTCAGATTCATTCGACTA-3'), which amplify a region of the gene corresponding to positions 14197 to 14675 of the bowhead whale (Arnason et al., 2004; accession AJ554051). Polymerase chain reaction (PCR) cycling conditions consisted of an initial five-minute denaturation step at $94^{\circ} \mathrm{C}$; 50 cycles of $94^{\circ} \mathrm{C}$ for 30 seconds, $60^{\circ} \mathrm{C}$ for one minute, and $72^{\circ} \mathrm{C}$ for one minute; and a final extension step at $65^{\circ} \mathrm{C}$ for 45 minutes. PCR cocktail conditions were as follows within a $50 \mu \mathrm{l}$ reaction: $5 \mu \mathrm{l}$ DNA extract, $1 \mathrm{X}$ PCR buffer (20 mM Tris- $\mathrm{HCl} \mathrm{pH} 8.4,50 \mathrm{mM} \mathrm{KCl}$ ) (Invitrogen, Burlington, $\mathrm{ON}$ ), $2 \mathrm{mM} \mathrm{MgCl} 2$ (Invitrogen, Burlington, $\mathrm{ON}$ ), $0.2 \mathrm{mM}$ each dNTP (Amersham Biosciences, 
Piscataway, NJ), $0.3 \mu \mathrm{g} / \mu \mathrm{l}$ BSA (Sigma, Oakville, ON), $0.1 \mathrm{U} / \mu 1 \mathrm{Taq}$ polymerase (Invitrogen, Burlington, ON), and $0.3 \mu \mathrm{M}$ of each primer.

To determine product quantity and quality, amplified mitochondrial DNA was electrophoresed within a $1.5 \%$ agarose gel stained with ethidium bromide and then visualized under UV light. The product was then purified for sequencing using the QIAquick $^{\circledR}$ PCR purification kit (Qiagen, Mississauga, ON) and sequenced in both directions with primers CBMYSTF1 and CBMYSTR using a MegaBACE ${ }^{\mathrm{TM}}$ DYEnamic ${ }^{\mathrm{TM}}$ ET dye terminator kit (GE Healthcare, Piscataway, NJ). Sequenced PCR product was then electrophoresed and visualized using a MegaBACETM 1000 (GE Healthcare, Piscataway, NJ) and analyzed with MegaBACE ${ }^{\text {TM }}$ Sequence Analyzer 3.0 software.

Sequences were first aligned and edited by eye and then aligned using Clustal X (Thompson et al., 1997). Distinct mitochondrial haplotypes were designated if the sequences were observed in at least two samples. Sequences observed only within a single sample were re-amplified and sequenced in both directions for confirmation. Likelihood ratio tests (implemented in MODELTEST version 3.7 [Posada and Crandall, 1998]) were used to determine the best-fit model of molecular evolution for the data set. Phylogenetic relationships between sequences were then determined in TREE-PUZZLE version 5.2 (Strimmer and von Haesler, 1996; Schmidt et al., 2002), using quartet puzzling maximum likelihood and 10000 puzzling steps. The Tamura-Nei model of molecular evolution (Tamura and Nei, 1993) with gamma-distributed rate variation across nucleotide sites (Yang, 1993, 1994) was used (as indicated by MODELTEST). One representative cytochrome $b$ sequence from each baleen whale species available in Genbank was included in the analyses, along with a sequence from the killer whale (Orcinus orca) as an outgroup sample. Representative whale species included in the phylogenetic analyses (Fig. 2), Genbank accession numbers, and original citations are included in Table 2.

The species of each bone specimen was identified by determining the known whale species each sample grouped with and confirming that primary branching patterns had more than $80 \%$ nodal support. Mean and pairwise haplotype distances were calculated in Mega 3.1 (Kumar et al., 2004) using a Tamura-Nei model of nucleotide substitution (Tamura and Nei, 1993) and gamma-distributed rate variation across sites (Yang, 1993, 1994). Nucleotide diversity $(\pi)(\mathrm{Nei}, 1987)$ and haplotype diversity (h) (Nei, 1987) were calculated using DnaSP (Rozas et al., 2003).

\section{Minimum Number of Individuals}

To identify the minimum number of individual whales within the sample set, the haplotype, sampling site, and bone type of the bone specimens were cross referenced. Samples were identified as coming from different individuals if they had different cytochrome $b$ haplotypes or were from different sampling sites. Samples with a shared

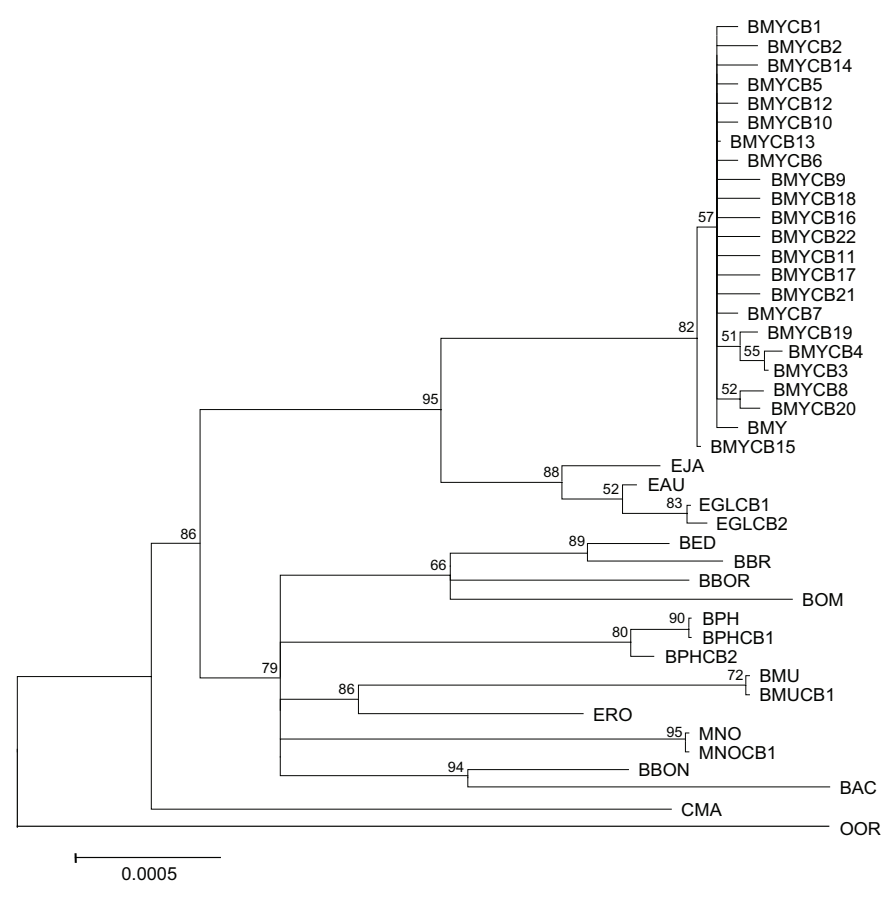

FIG. 2. Quartet maximum likelihood phylogenetic tree of cytochrome $b$ sequences from 16th-century bone samples analyzed in this study, representative baleen whale sequences, and a killer whale (O. orca) outgroup sequence obtained from genbank. Numerical values on the branches indicate the percentage of 10000 quartet puzzling steps supporting this branching pattern.

haplotype and site location, yet from a bone type existing only singly in a skeleton (e.g., right humerus, cervical 1-7 vertebrae), were also identified as different individuals.

\section{RESULTS}

Between 1999 and 2005, whale bones were sampled at 10 of the 20 Basque sites investigated in Quebec and Labrador, Canada (Table 1). Bones were not found at the remaining ten sites. A total of 364 bone specimens were sampled. These included 85 bones found underwater during the 1978-85 marine excavation of the San Juan in Red Bay, Labrador (Barkham, 1984; Tuck, 1985; Grenier, 1985), sampled from the collection of the Red Bay National Historic Site of Parks Canada; 87 bones sampled from the harbour of Red Bay during the 2004 Parks Canada marine refurbishment of the sunken galleon site; 191 bones found in terrestrial deposits at various sites, including samples from the collections of the Whiteley Museum (Rivière St. Paul, QC), the Centre de conservation du Québec (Québec, $\mathrm{QC}$ ), and the Parc de l'aventure basque en Amérique (TroisPistoles, QC); and one bone sampled during the Gateways/ Smithsonian Institution marine investigation of Petit Mécatina, Quebec, now in the collection of the Centre de conservation du Québec (Québec, QC) (Table 1). Three sites with relatively large concentrations of whale bones were Red Bay, Chateau Bay/Henley Harbour, and Pleasure Harbour. At these sites, bones that can be found only singly within an individual, such as skulls and the fused cervical 
$66 \cdot$ B.A. McLEOD et al

TABLE 2. Species abbreviation, scientific and common names, accession number, and source reference for representative whale cytochrome $b$ sequences of species included in the phylogenetic tree (Fig. 2).

\begin{tabular}{|c|c|c|c|}
\hline Abbreviation & Species & Accession Number & Reference \\
\hline BAC & Balaenoptera acutorostrata (minke whale) & AJ554054 & Arnason et al., 2004 \\
\hline BBOR & Balaenoptera borealis (sei whale) & AP006470 & Sasaki et al., 2005 \\
\hline BBON & Balaenoptera bonaerensis (Antarctic minke whale) & AP006466 & Sasaki et al., 2005 \\
\hline BBR & Balaenoptera brydei (Bryde's whale) & AP006469 & Sasaki et al., 2005 \\
\hline BED & Balaenoptera edeni (pygmy Bryde's whale) & AB201258 & Sasaki et al., 2006 \\
\hline BMU & Balaenoptera musculus (blue whale) & X72204 & Arnason and Gullberg, 1993 \\
\hline BMY & Balaena mysticetus (bowhead whale) & AJ554051 & Arnason et al., 2004 \\
\hline BOM & Balaenoptera omurai (Omura's whale) & AB201257 & Sasaki et al., 2006 \\
\hline $\mathrm{BPH}$ & Balaenoptera physalus (fin whale) & X61145 & Arnason et al., 1991 \\
\hline CMA & Caperea marginata (pygmy right whale) & X75586 & Arnason and Gullberg, 1994 \\
\hline EAU & Eubalaena australis (southern right whale) & AP006473 & Sasaki et al., 2005 \\
\hline EGL & Eubalaena glacialis (North Atlantic right whale) & AY398662 & Rychel et al., 2004 \\
\hline EJA & Eubalaena japonica (North Pacific right whale) & AP006474 & Sasaki et al., 2005 \\
\hline ERO & Eschrichtius robustus (gray whale) & X75585 & Arnason and Gullberg, 1994 \\
\hline MNO & Megaptera novaeangliae (humpback whale) & AP006467 & Sasaki et al., 2005 \\
\hline OOR & Orcinus orca (killer whale) & AF084060 & Leduc et al., 1999 \\
\hline
\end{tabular}

vertebrae (1-7), were preferentially sampled, while at other sites all available bone specimens were sampled.

To identify the species of origin of the specimens, DNA was extracted and cytochrome $b$ sequences were amplified from a subset of the bone samples $(n=218)$. This subset encompasses all samples from sites where fewer than 20 samples were found, and 182 samples from three sites of historical importance: 141 from Red Bay, 22 from Chateau Bay, and 19 from Pleasure Harbour. At these three sites, samples with a greater likelihood of representing a single individual were preferentially extracted. Cytochrome $b$ sequences were also obtained from six contemporary right whale and bowhead "control" specimens ( 2 E. glacialis, 4 B. mysticetus).

The phylogenetic tree using maximum likelihood inference of phylogeny identified five species within the sequences from 218 bones: bowhead whale $(n=203)$, right whale $(\mathrm{n}=1)$, humpback whale (Megaptera novaeangliae) $(\mathrm{n}=6)$, fin whale (Balaenoptera physalus) $(\mathrm{n}=7)$, and blue whale (B. musculus) $(\mathrm{n}=1)$ (Fig. 2, Table 3). To estimate the minimum number of individuals represented within the sample set, we cross-referenced the sampling location, species, haplotype, and bone types of the samples collected. We determined that the sample subset $(n=218)$ consists of a minimum of 80 individuals, encompassing one right whale, one blue whale, and at least three fin whales, three humpback whales, and 72 bowhead whales, with no perceivable pattern of distribution of species across sites. The minimum number of individuals identified at each site is indicated in Table 1.

Among the 224 samples sequenced (including bones and control samples), 28 haplotypes were identified, encompassing 458 bp spanning positions (14 197-14655) of the bowhead whale (Table 3; Genbank accession numbers EU303313-EU303340). Four haplotypes were identical to the sequences of several species included from Genbank $(\mathrm{BMY}=\mathrm{BMYCB} 7, \mathrm{BPH}=\mathrm{BPHCB} 1, \mathrm{MNO}=$ MNOCB 1, BMU = BMUCB1) (Fig. 2). Twenty-two of the 28 haplotypes were identified as bowhead whale in the phylogenetic tree (Fig. 2). These haplotypes encompass 20 variable sites, all of which are transitions (Table 3). Of these 22 haplotypes, two had relatively high frequencies (BMYCB7, $\mathrm{n}=102$, and BMYCB13, $\mathrm{n}=41$ ), while the remaining 20 were present in only $1-16$ specimens each (Table 3). Three haplotypes (EGLCB2, BMYCB19, BMYCB22) were found only in the "control" contemporary right and bowhead whale samples and not within any historical specimens.

To determine the amount of sequence variation present within the bowhead cytochrome $b$ haplotypes, we calculated mean within-species distance (0.006, SE 0.002) and compared this to the mean sequence distance for all baleen whale haplotypes $(n=15$, calculated using one haplotype from each species included in the phylogenetic tree) $(0.038$, SE 0.010). Nucleotide polymorphism (P), nucleotide diversity $(\pi)$, and haplotype diversity (h) for the bowhead sequences were 0.039, 0.003 (SE 0.00018), and 0.697 (SE 0.029) respectively. Note that this calculation of haplotype diversity is likely downward biased, as multiple bones may be from a single individual.

\section{DISCUSSION}

Genetic analyses of Rastogi et al. (2004) suggested that instead of large numbers of both right and bowhead whales being hunted by the Basques in the epicenter of their Strait of Belle Isle and Gulf of St. Lawrence whale fishery during the 16th and 17th centuries (Red Bay, Labrador), the bowhead whale was the primary species hunted. This finding was significant because it was the first observation to call into question previous suggestions that this period of whaling was responsible for removing large numbers of right whales (approximately half [Cumbaa, 1986] of an estimated 25000 40000 kills between approximately 1530 and 1610 [Aguilar, 1986]) from the supposed historical population of right whales in this region. However, this work was based upon a relatively small sample set $(n=21)$ from a single whaling 
port. To further investigate the whale species comprising the 16th- and 17th-century Basque catch in the western North Atlantic we identified the species of origin of a much larger number of bone specimens remaining in marine and terrestrial deposits from the majority of identified Basque sites along the coasts of Quebec and Labrador, Canada. In concordance with the results of Rastogi et al. (2004), mitochondrial cytochrome $b$ analysis revealed that the majority of the bone specimens collected are from bowhead whales, suggesting that this species was the principal target species of the hunt. The finding of only a single right whale bone suggests that this hunt had a minimal impact on the species (in terms of numbers of whales killed) and does not support the suggestion that the Basques killed 12000-15000 right whales in this region (Gaskin, 1991), a removal which has been thought to have been a primary cause of the decline of the species in the western North Atlantic. The presence of fin, blue, and humpback whales within the sample set may be a result of the occasional hunt of rorqual species or natural whale stranding events, or both. However, despite the variety of species identified, this whaling clearly had a much larger impact on the 16th-century North Atlantic population of bowhead whales than has previously been recognized.

The bowhead whale population(s) currently found in the eastern Arctic (Baffin Bay/Davis Strait) have a distribution ranging from $\sim 60^{\circ} \mathrm{N}$ to $85^{\circ} \mathrm{N}$ (Moore and Reeves, 1993; Fig. 1), and thus it is surprising to find 16th- to 17thcentury bowhead whale specimens as far south as $50^{\circ} \mathrm{N}$ (Petit Mécatina, QC) and $48^{\circ} \mathrm{N}$ (Île aux Basques, QC). The presence of bowhead whales at these sites that were occupied during the late 16th-century (Table 1) provides proof of very recent occupation of the area by this species. Because whaling operations were shore-based (that is, whales were observed from shore and then hunted from several small boats or chalupas) (Reeves and Smith, 2006), the whale bones identified are representative of the whales found in the area. However, it remains to be determined whether the presence of the bowhead whale in this area is a result of a wider distribution of a historically larger population prior to whaling, or a reflection of the climatic cooling induced by the Little Ice Age (Lamb, 1995), which may have excluded bowheads from more northerly extensions of their range, or both. Although stranded bowheads have been found twice in recent times around Newfoundland (Ledwell et al., 2007), the most recent "physical" indication of bowhead whales occupying this more southerly region near the mouth of the St. Lawrence River date to the age of the Champlain Sea (10000-13000 years ago) (e.g., Cameron, 1951; Harington, 1977). However, species identification has not been genetically confirmed. If the change in distribution of bowheads was due to climatic phenomena, it is also reasonable to question how this may also have affected the distribution of the right whale in the western North Atlantic.

Despite what is known about the climatic affects of the Little Ice Age, it is difficult to evaluate exactly how the distributions and migratory patterns of these species may have been affected. The Little Ice Age, which lasted from $\sim 1400$ to $\sim 1850$, was characterized by colder conditions that caused glacial advancement, decreased sea surface temperatures, increased sea ice, and by an expanded Arctic front (Lamb, 1995). During this time, climatic cooling led to colder summer temperatures (Schledermann, 1976; Kreutz et al., 1997), increased storminess, and an increased thermal gradient between approximately $50^{\circ}$ and $65^{\circ} \mathrm{N}$ (Lamb, 1995). These conditions may have led to a more southerly distribution of the bowhead whale as a result of an expanded Arctic front (Schledermann, 1976; De Jong, 1983; Moore and Reeves, 1993). In fact, 16th-century Thule people abandoned areas of northern Greenland and the central/ northern Canadian Arctic, likely as a result of reduced access to marine mammals (Schledermann, 1976; McGhee, 1969/70; Stoker and Krupnik, 1993; Henshaw, 2003). Increased sea ice and colder summer conditions may have resulted in a temporally shifted whale migration, perhaps with longer annual occupancy of more southerly areas of its historic distribution.

Such conditions may have also resulted in a more southerly distribution of the right whale. The Strait of Belle Isle has often been cited as a historical right whale habitat area that has never been re-occupied (e.g., Greene et al., 2003; Greene and Pershing, 2004). But, given the results of our analysis, it appears that the region was not frequented by this species during the period in question. In general, the distributional ecology of both species is very complex and likely influenced by a variety of factors, including (but not limited to) sea surface temperature, ice thickness and concentration, regional/seasonal/annual variability, food availability, and oceanographic processes (such as areas of upwelling) (Moore and Reeves, 1993; Moore et al., 2000). However, it is likely that climatic changes of the Little Ice Age affected both the distribution and the migratory patterns of these species both temporally and spatially.

Characteristics of the timing of the 16th-century Basque hunt in the Strait of Belle Isle revealed by historical research appeared to support the original hypothesis that both right whales and bowhead whales were targeted. In the 1540s, the Basques arrived in the region for the "coming of the whales" (la venida de las ballenas) or "summer whaling season" in June/July, following which they returned to Europe. However, in the 1550s, after discovering a second influx of whales in September/October, they began staying later for the "return of the whales" (el retorno de las ballenas) or "winter whaling season" (Huxley [Barkham], 1987; M. Barkham, pers. comm. 2005). It has frequently been suggested, partly on the basis of the present-day migratory timing and distribution of these two species, that the whales hunted during the summer were a different species from those hunted during the winter (e.g., Eschricht and Reinhardt, 1866; Reeves et al., 1983; Cumbaa, 1986; Reeves and Mitchell, 1986; Woodby and Botkin, 1993). Under this hypothesis, the right whale, 
$68 \cdot$ B.A. McLEOD et al.

TABLE 3. Variable sites for the haplotypes obtained in this study (Genbank accession EU303313-EU303340) and their frequencies. The reference sequence (AF554051) matches BMYCB7. Dots indicate sequence similarity to the reference sequence. Numbers in parentheses indicate the number of haplotypes that were additionally found in control samples.

\begin{tabular}{|c|c|c|c|c|c|c|c|c|c|c|c|c|c|c|c|c|c|c|c|c|c|c|c|}
\hline Seq Position & 39 & 40 & 42 & 45 & 46 & 48 & 49 & 51 & 55 & 57 & 60 & 63 & 66 & 69 & 78 & 79 & 84 & 87 & 93 & 96 & 102 & 111 & 117 \\
\hline AF554051 & $\mathrm{T}$ & A & $\mathrm{T}$ & $\mathrm{T}$ & G & $\mathrm{C}$ & G & C & A & C & C & C & $\mathrm{C}$ & C & $\mathrm{T}$ & A & $\mathrm{T}$ & A & A & $\mathrm{C}$ & $\mathrm{T}$ & $\mathrm{T}$ & $\mathrm{T}$ \\
\hline BMYCB 1 & . & . & . & . & . & . & . & . & . & . & . & . & . & . & $\mathrm{C}$ & . & . & . & . & . & . & . & . \\
\hline BMYCB 2 & . & . & . & . & . & . & . & . & . & . & . & . & . & . & $\mathrm{C}$ & . & . & . & . & . & . & . & . \\
\hline BMYCB 3 & . & . & . & . & A & . & . & . & . & . & . & . & . & . & $\mathrm{C}$ & . & . & . & . & . & . & . & . \\
\hline BMYCB 4 & & . & . & . & A & . & . & . & . & . & . & . & . & . & $\mathrm{C}$ & . & . & . & . & . & . & . & . \\
\hline BMYCB 5 & $\mathrm{C}$ & . & . & . & . & . & . & . & . & . & . & . & . & . & . & . & . & . & . & . & . & . & . \\
\hline ВMYCB 6 & . & . & . & . & . & . & . & . & . & . & . & . & . & . & . & G & . & . & . & . & . & . & . \\
\hline BMYCB 7 & . & . & . & . & . & . & . & . & . & . & . & . & . & . & . & . & . & . & . & . & . & . & . \\
\hline BMYCB 8 & . & . & . & . & . & . & . & . & . & . & . & . & . & . & . & . & . & . & . & . & . & . & . \\
\hline BMYCB 9 & . & . & . & . & . & . & . & . & . & . & . & . & . & . & . & . & . & . & . & . & . & . & . \\
\hline BMYCB 10 & . & . & . & . & . & . & . & . & . & . & . & . & . & . & . & . & . & . & . & . & . & . & . \\
\hline BMYCB 11 & . & . & . & . & . & . & . & . & . & . & . & . & . & . & . & . & . & . & . & . & . & . & . \\
\hline BMYCB 12 & . & . & . & . & . & . & . & . & . & . & . & . & . & . & . & . & . & . & . & . & . & . & . \\
\hline BMYCB 13 & . & . & . & . & . & . & . & . & . & . & . & . & . & . & . & . & . & . & . & . & . & . & . \\
\hline BMYCB 14 & . & . & . & . & . & . & . & . & . & . & . & . & . & . & $\mathrm{C}$ & . & . & . & . & . & . & . & . \\
\hline BMYCB 15 & . & . & . & . & . & . & . & . & . & . & . & . & . & . & . & . & . & . & . & . & . & . & . \\
\hline BMYCB 16 & . & . & . & . & . & . & . & . & . & . & . & . & . & . & . & . & . & . & . & . & . & . & . \\
\hline ВМYСВ 17 & . & . & . & . & . & . & . & . & . & . & . & . & . & . & . & . & . & . & . & . & . & . & . \\
\hline BMYCB 18 & . & . & . & . & . & . & . & . & . & . & . & . & . & . & . & . & . & . & . & . & . & . & . \\
\hline BMYCB 19 & . & . & . & . & . & . & . & . & . & . & . & . & . & . & C & . & . & . & . & . & . & . & . \\
\hline BMYCB 20 & . & . & . & . & . & . & . & . & . & . & . & . & . & . & $\mathrm{C}$ & . & . & & . & . & . & . & . \\
\hline BMYCB 21 & . & . & . & . & . & . & . & . & . & . & . & . & . & . & . & . & . & G & . & . & . & . & . \\
\hline BMYCB 22 & . & . & . & . & . & . & . & . & . & . & . & . & . & . & . & . & . & . & . & . & . & . & . \\
\hline EGLCB 1 & . & . & . & . & . & . & . & . & . & . & $\mathrm{T}$ & . & . & $\mathrm{T}$ & . & . & . & . &. & $\mathrm{T}$ & $\mathrm{C}$ & . & . \\
\hline EGLCB 2 & . & . & . & . & . & . & . & . & . & . & $\mathrm{T}$ & . & . & $\mathrm{T}$ & . & . & . & . & . & $\mathrm{T}$ & . & . & . \\
\hline BPHCB 1 & $\mathrm{C}$ & $\mathrm{G}$ & $\mathrm{C}$ & $\mathrm{C}$ &. & . & . & $\mathrm{A}$ & $\mathrm{G}$ & . & $\mathrm{T}$ & . & . & . & . & . & . & . & G & . & $\mathrm{C}$ & $\mathrm{C}$ & $\mathrm{C}$ \\
\hline ВРНСВ 2 & $\mathrm{C}$ & $\mathrm{G}$ & $\mathrm{C}$ & $\mathrm{C}$ & . & . & . & A & G & . & $\mathrm{T}$ & . & . & . & . & . & . & . & G & . & . & $\mathrm{C}$ & $\mathrm{C}$ \\
\hline MNOCB 1 & . & . & $\mathrm{C}$ & $\mathrm{C}$ & . & . & A & A & . & $\mathrm{T}$ & $\mathrm{T}$ & A & . & . & . & . & $\mathrm{C}$ & . & . & . & . & $\mathrm{C}$ & . \\
\hline BMUCB 1 & $\mathrm{C}$ & . & $\mathrm{C}$ & $\mathrm{C}$ & . & $\mathrm{T}$ & . & $\mathrm{A}$ & . & $\mathrm{T}$ & $\mathrm{T}$ & . & $\mathrm{T}$ & . & $\mathrm{C}$ & . & $\mathrm{C}$ & . & . & . & $\mathrm{C}$ & $\mathrm{C}$ & $\mathrm{C}$ \\
\hline
\end{tabular}

\begin{tabular}{|c|c|c|c|c|c|c|c|c|c|c|c|c|c|c|c|c|c|c|c|c|c|c|c|}
\hline Seq Position & 120 & 121 & 123 & 126 & 127 & 165 & 174 & 179 & 196 & 198 & 204 & 207 & 210 & 219 & 222 & 225 & 227 & 232 & 234 & 237 & 240 & 243 & 244 \\
\hline AF554051 & $\mathrm{C}$ & $\mathrm{C}$ & G & $\mathrm{T}$ & A & C & $\mathrm{T}$ & C & A & $\mathrm{T}$ & $\mathrm{C}$ & $\mathrm{C}$ & $\mathrm{T}$ & A & $\mathrm{C}$ & $\mathrm{C}$ & $\mathrm{T}$ & A & $\mathrm{C}$ & $\mathrm{C}$ & A & $\mathrm{T}$ & $\mathrm{T}$ \\
\hline BMYCB 1 & . & . & . & . & . & . & . & . & . & . & . & . & . & . & . & . & . & . & . & . & . & . & . \\
\hline BMYCB 2 & . & . & . & $\mathrm{C}$ & . & . & . & . & . & . & . & . & . & . & . & . & . & . & . & . & . & . & . \\
\hline BMYCB 3 & . & . & . & . & . & . & . & . & . & . & . & . & . & . & . & . & . & . & . & . & . & . & . \\
\hline BMYCB 4 & . & . & . & . & . & . & . & . & . & . & . & . & . & . & . & . & . & . & . & . & . & . & . \\
\hline BMYCB 5 & . & . & . & . & . & . & . & . & . & . & . & . & . & . & . & . & . & . & . & . & . & . & . \\
\hline BMYCB 6 & . & . & . & . & . & . & . & . & . & . & . & . & . & . & . & . & . & . & . & . & . & . & . \\
\hline BMYCB 7 & . & . & . & . & . & . & . & . & . & . & . & . & . & . & . & . & . & . & . & . & . & . & . \\
\hline BMYCB 8 & . & . & . & . & . & . & . & . & . & . & . & . & . & . & . & . & . & . & . & . & . & . & . \\
\hline BMYCB 9 & . & . & . & . & . & . & . & . & . & . & . & . & . & . & . & . & . & . & . & . & . & . & . \\
\hline BMYCB 10 & . & . & . & . & . & . & . & . & . & . & . & . & . & . & . & . & . & . & $\cdot$ & . & . & . & . \\
\hline BMYCB 11 & . & . & . & . & . & . & . & . & . & . & . & . & . & . & . & . & . & . & $\cdot$ & $\cdot$ & $\cdot$ & . & . \\
\hline BMYCB 12 & . & . & . & . & . & . & . & . & . & . & . & . & . & . & . & . & . & . & . & . & . & . & . \\
\hline BMYCB 13 & . & . & . & . & . & . & . & . & . & . & . & . & . & . & . & . & . & . & . & . & . & . & . \\
\hline BMYCB 14 & . & . & . & . & . & . & . & . & . & . & . & . & . & . & . & $\mathrm{T}$ & . & . & . & . & . & . & . \\
\hline BMYCB 15 & . & . & . & . & . & . & . & . & . & . & . & . & . & . & . & $\cdot$ & . & . & . & . & . & . & . \\
\hline BMYCB 16 & . & . & . & . & . & . & . & . & . & . & . & . & . & . & $\cdot$ & . & . & . & . & . & . & . & . \\
\hline BMYCB 17 & . & . & . & . & . & . & . & . & . & . & . & . & . & . & . & . & . & . & . & . & . & . & . \\
\hline BMYCB 18 & . & . & . & . & . & . & . & . & . & . & . & . & . & . & . & . & . & . & . & . & . & . & . \\
\hline BMYCB 19 & . & . & . & . & . & . & . & . & . & . & . & . & . & . & . & . & . & . & . & . & . & . & . \\
\hline BMYCB 20 & . & . & . & . & . & . & . & . & . & . & . & . & . & . & . & . & . & . & . & . & . & . & . \\
\hline BMYCB 21 & . & . & . & . & . & . & . & . & . & . & . & . & . & . & . & . & . & . & . & . & . & . & . \\
\hline BMYCB 22 & . & . & . & . & . & . & . & . & . & . & . & . & . & . & . & . & . & . & . & . & . & . & . \\
\hline EGLCB 1 & $\mathrm{~T}$ & . & A & . & . & . & $\mathrm{C}$ & . & . & $\mathrm{C}$ & . & . & . & . & . & . & . & . & $\mathrm{T}$ & . & . & . & . \\
\hline EGLCB 2 & $\mathrm{~T}$ & . & A & . & . & . & $\mathrm{C}$ & . & . & $\mathrm{C}$ & . & . & . & . & . & . & . & . & $\mathrm{T}$ & . & . & . & . \\
\hline BPHCB 1 & . & $\mathrm{T}$ & A & . & . & . & $\mathrm{C}$ & . & $\mathrm{G}$ & $\mathrm{C}$ & . & . & $\mathrm{C}$ & $\mathrm{G}$ & $\mathrm{T}$ & . & $\mathrm{C}$ & . & $\mathrm{T}$ & . & . & $\mathrm{C}$ & \\
\hline ВРНСВ 2 & . & . & A & . & . & . & $\mathrm{C}$ & . & G & $\mathrm{C}$ & . & . & $\mathrm{C}$ & $\mathrm{G}$ & $\mathrm{T}$ & . & $\mathrm{C}$ & . & $\mathrm{T}$ & . & . & $\mathrm{C}$ & \\
\hline MNOCB 1 & . & $\mathrm{T}$ & A & . & . & . & $\mathrm{C}$ & . & G & $\mathrm{C}$ & . & . & . & . & $\mathrm{T}$ & $\mathrm{T}$ & $\mathrm{C}$ & . & $\mathrm{T}$ & . & . & $\mathrm{C}$ & . \\
\hline BMUCB 1 & . & $\mathrm{T}$ & A & . & G & $\mathrm{T}$ & $\mathrm{C}$ & $\mathrm{T}$ & $\mathrm{G}$ & $\mathrm{C}$ & $\mathrm{T}$ & $\mathrm{T}$ & $\mathrm{C}$ & . & . & $\mathrm{T}$ & $\mathrm{C}$ & $\mathrm{G}$ & $\mathrm{T}$ & $\mathrm{T}$ & G & $\mathrm{C}$ & $\mathrm{T}$ \\
\hline
\end{tabular}


TABLE 3 continued:

\begin{tabular}{|c|c|c|c|c|c|c|c|c|c|c|c|c|c|c|c|c|c|c|c|c|c|c|c|}
\hline Seq Position & 249 & 255 & 258 & 261 & 264 & 276 & 286 & 288 & 294 & 297 & 300 & 301 & 303 & 312 & 319 & 322 & 324 & 326 & 327 & 329 & 342 & 345 & 348 \\
\hline AF554051 & $\mathrm{T}$ & $\mathrm{T}$ & A & $\mathrm{C}$ & $\mathrm{C}$ & $\mathrm{C}$ & G & $\mathrm{T}$ & $\mathrm{A}$ & A & $\mathrm{T}$ & G & $\mathrm{C}$ & $\mathrm{T}$ & $\mathrm{C}$ & G & $\mathrm{C}$ & $\mathrm{T}$ & $\mathrm{T}$ & $\mathrm{A}$ & $\mathrm{C}$ & $\mathrm{T}$ & $\mathrm{G}$ \\
\hline BMYCB 1 & . & . & . & . & . & . & . & . & . & . & . & . & . & . & . & . & . & . & . & . & . & . & . \\
\hline BMYCB 2 & . & . & . & . & . & . & . & . & . & . & . & . & . & . & . & . & . & . & . & . & . & . & . \\
\hline BMYCB 3 & . & . & . & . & . & . & . & . & . & . & . & . & . & . & . & . & . & . & . & . & . & . & . \\
\hline BMYCB 4 & . & . & . & . & . & . & . & . & . & . & . & . & . & . & . & A & . & . & . & . & . & . & . \\
\hline BMYCB 5 & . & . & . & . & . & . & . & . & . & . & . & . & . & . & . & . & . & . & . & . & . & . & . \\
\hline BMYCB 6 & . & . & . & . & . & . & . & . & . & . & . & . & . & . & . & . & . & . & . & . & . & . & . \\
\hline BMYCB 7 & . & . & . & . & . & . & . & . & . & . & . & . & . & . & . & . & . & . & . & . & . & . & . \\
\hline BMYCB 8 & . & . & . & . & . & . & A & . & . & . & . & . & . & . & . & . & . & . & . & . & . & . & . \\
\hline BMYCB 9 & . & . & . & . & . & . & . & A & . & . & . & . & . & . & . & . & . & . & . & . & . & . & . \\
\hline BMYCB 10 & . & . & . & . & . & . & . & . & . & G & . & . & . & . & . & . & . & . & . & . & . & . & . \\
\hline BMYCB 11 & . & . & . & . & . & . & . & . & . & . & . & . & . & . & . & . & . & $\mathrm{C}$ & . & . & . & . & . \\
\hline BMYCB 12 & . & . & . & . & . & . & . & . & . & . & . & . & . & . & . & . & . & . & . & . & . & . & . \\
\hline BMYCB 13 & . & . & . & . & . & . & . & . & . & . & . & . & . & . & . & . & . & . & . & . & . & . & . \\
\hline BMYCB 14 & . & . & . & . & . & . & . & . & . & . & . & . & . & . & . & . & . & . & . & . & . & . & . \\
\hline BMYCB 15 & . & . & . & . & . & . & . & . & . & . & . & . & . & . & . & . & . & . & . & . & . & . & . \\
\hline BMYCB 16 & . & . & . & . & . & . & . & . & . & . & . & . & . & . & . & . & . & . & . & . & . & . & . \\
\hline ВMYCB 17 & . & . & . & . & . & . & . & . & . & . & . & . & . & . & . & . & . & . & . & . & . & . & . \\
\hline BMYCB 18 & . & . & . & . & . & . & . & . & . & . & . & A & . & . & . & . & . & . & . & . & . & . & . \\
\hline ВMYCB 19 & . & . & . & . & . & . & . & . & . & . & . & . & . & . & . & A & . & . & . & . & . & . & . \\
\hline BMYCB 20 & . & . & . & . & . & . & A & . & . & . & . & . & . & . & . & . & . & . & . & . & . & . & . \\
\hline BMYCB 21 & . & . & . & . & . & . & . & . & . & . & . & . & . & . & . & . & . & . & . & . & . & . & . \\
\hline BMYCB 22 & $\mathrm{C}$ & . & . & . & . & . & . & . & . & . & . & . & . & & . & & 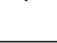 & & $\cdot$ & $\cdot$ & 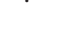 & 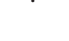 & 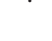 \\
\hline EGLCB 1 & . & $\mathrm{C}$ & . & . & . & $\mathrm{T}$ & . & $\mathrm{C}$ & . & . & $\mathrm{C}$ & . & . & $\mathrm{C}$ & $\mathrm{T}$ & . & . & . & $\mathrm{C}$ & . & . & . & A \\
\hline EGLCB 2 & . & $\mathrm{C}$ & . & . & . & $\mathrm{T}$ & . & $\mathrm{C}$ & . & . & $\mathrm{C}$ & . & . & $\mathrm{C}$ & $\mathrm{T}$ & . & . & . & $\mathrm{C}$ & . & . & . & $\mathrm{A}$ \\
\hline BPHCB 1 & . & . & G & $\mathrm{T}$ & $\mathrm{T}$ & . & . & . & . & . & A & . & . & $\mathrm{C}$ & $\mathrm{T}$ & . & . & . & $\mathrm{C}$ & G & $\mathrm{T}$ & . & A \\
\hline ВРНСВ 2 & . & . & G & $\mathrm{T}$ & $\mathrm{T}$ & . & . & $\mathrm{C}$ & . & . & A & . & . & $\mathrm{C}$ & $\mathrm{T}$ & . & . & . & $\mathrm{C}$ & G & $\mathrm{T}$ & . & A \\
\hline MNOCB 1 & . & . & $\mathrm{G}$ & . & . & . & . & . & . & . & $\mathrm{A}$ & . & . & $\mathrm{C}$ & $\mathrm{T}$ & . & . & . & $\mathrm{C}$ & $\mathrm{G}$ & . & $\mathrm{C}$ & $\mathrm{A}$ \\
\hline BMUCB 1 & . & $\mathrm{C}$ & . & . & . & . & . & $\mathrm{C}$ & $\mathrm{G}$ & . & $\mathrm{A}$ & . & $\mathrm{T}$ & $\mathrm{C}$ & & & $\mathrm{T}$ & 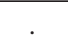 & . & $\mathrm{G}$ & $\mathrm{T}$ & . & $\mathrm{A}$ \\
\hline
\end{tabular}

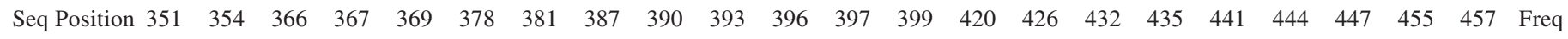

\begin{tabular}{|c|c|c|c|c|c|c|c|c|c|c|c|c|c|c|c|c|c|c|c|c|c|c|c|}
\hline AF554051 & A & $\mathrm{C}$ & A & G & $\mathrm{C}$ & $\mathrm{T}$ & A & G & $\mathrm{C}$ & $\mathrm{T}$ & $\mathrm{C}$ & $\mathrm{T}$ & A & $\mathrm{T}$ & $\mathrm{C}$ & $\mathrm{C}$ & $\mathrm{C}$ & $\mathrm{C}$ & $\mathrm{T}$ & $\mathrm{C}$ & $\mathrm{C}$ & A & \\
\hline BMYCB 1 & . & . & . & . & . & . & . & . & . & . & . & $\mathrm{C}$ & . & . & . & . & . & . & . & . & . & $\mathrm{G}$ & $16(2)$ \\
\hline BMYCB 2 & . & . & . & . & . & . & . & . & . & . & . & $\mathrm{C}$ & . & . & . & . & . & . & . & . & . & $\mathrm{G}$ & 4 \\
\hline BMYCB 3 & . & . & . & . & . & . & . & . & . & . & . & $\mathrm{C}$ & . & . & . & . & . & . & . & . & . & G & 13 \\
\hline BMYCB 4 & . & . & . & . & . & . & . & . & . & . & . & $\mathrm{C}$ & . & . & . & . & . & . & . & . & . & G & 1 \\
\hline BMYCB 5 & . & . & . & . & . & . & . & . & . & . & . & $\mathrm{C}$ & . & . & . & . & . & . & . & . & . & . & 1 \\
\hline ВMYCB 6 & . & . & . & . & . & . & . & . & . & . & . & $\mathrm{C}$ & . & . & . & . & . & . & . & . & . & . & 1 \\
\hline BMYCB 7 & . & . & . & . & . & . & . & . & . & . & . & . & . & . & . & . & . & . & . & . & . & . & 102 \\
\hline BMYCB 8 & . & . & . & . & . & . & . & . & . & . & . & . & . & . & . & . & . & . & . & . & . & . & 3 \\
\hline ВМYCB 9 & . & . & . & . & . & . & . & . & . & . & . & . & . & . & . & . & . & . & . & . & . & . & 1 \\
\hline ВMYCB 10 & . & . & . & . & . & . & . & . & . & . & . & $\mathrm{C}$ & . & . & . & . & . & . & . & . & . & . & 8 \\
\hline ВMYCB 11 & . & . & . & . & . & . & . & . & . & . & . & . & . & . & . & . & . & . & . & . & . & . & 1 \\
\hline BMYCB 12 & . & . & . & A & . & . & . & . & . & . & . & $\mathrm{C}$ & . & . & . & . & . & . & . & . & . & . & 1 \\
\hline BMYCB 13 & . & . & . & . & . & . & . & . & . & . & . & $\mathrm{C}$ & . & . & . & . & . & . & . & . & . & & 41 \\
\hline ВМYCB 14 & . & . & . & . & . & . & . & . & . & . & . & $\mathrm{C}$ & . & . & . & . & . & . & . & . & . & G & 1 \\
\hline BMYCB 15 & . & . & . & . & . & . & . & A & . & . & 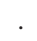 & $\mathrm{C}$ & . & . & . & . & . & . & . & . & . & . & 2 \\
\hline ВMYCB 16 & . & . & . & . & . & . & . & . & & . & $\mathrm{T}$ & . & . & . & . & . & . & . & . & . & . & . & 2 \\
\hline BMYCB 17 & . & . & . & . & . & . & . & . & $\mathrm{T}$ & . & . & . & . & . & . & . & . & . & . & . & . & . & 2 \\
\hline BMYCB 18 & . & . & . & . & . & . & . & . & . & . & . & . & . & . & . & . & . & . & . & . & . & . & 1 \\
\hline ВMYCВ 19 & . & . & . & . & . & . & . & . & . & . & . & $\mathrm{C}$ & . & . & . & . & . & . & . & . & . & $\dot{\mathrm{G}}$ & (1) \\
\hline BMYCB 20 & . & . & . & . & . & . & . & . & . & . & . & $\mathrm{C}$ & . & . & . & . & . & . & . & . & . & G & 1 \\
\hline BMYCB 21 & . & . & . & . & . & . & . & . & . & . & . & . & . & . & . & . & . & . & . & . & . & . & 1 \\
\hline BMYCB 22 & . & . & . & . & . & . & . & . & . & . & . & . & . & . & . & . & . & . & . & . & . & . & (1) \\
\hline$\overline{\text { EGLCB } 1}$ & . & . & . & . & . & . & G & . & . & . & . & $\mathrm{C}$ & G & $\mathrm{C}$ & $\mathrm{T}$ & . & . & . & . & . & . & . & 1(1) \\
\hline EGLCB 2 & . & . & . & . & . & . & G & . & . & . & . & C & G & C & $\mathrm{T}$ & . & . & . & . & . & . & . & (1) \\
\hline BPHCB 1 & $\mathrm{~T}$ & $\mathrm{~T}$ & . & . & $\mathrm{T}$ & $\mathrm{C}$ & . & A & . & $\mathrm{C}$ & . & $\mathrm{C}$ & G & $\mathrm{C}$ & . & $\mathrm{T}$ & A & $\mathrm{T}$ & $\mathrm{C}$ & . & . & . & 6 \\
\hline ВРНСВ 2 & $\mathrm{~T}$ & $\mathrm{~T}$ & . & . & $\mathrm{T}$ & $\mathrm{C}$ & . & A & . & $\mathrm{C}$ & . & $\mathrm{C}$ & G & $\mathrm{C}$ & . & $\mathrm{T}$ & A & . & $\mathrm{C}$ & . & . & . & 1 \\
\hline MNOCB 1 & $\mathrm{~T}$ & $\mathrm{~T}$ & . & . & $\mathrm{T}$ & . & . & A & . & $\mathrm{C}$ & . & $\mathrm{C}$ & . & $\mathrm{C}$ & . & . & . & . & $\mathrm{C}$ & $\mathrm{T}$ & . & . & 6 \\
\hline BMUCB 1 & $\mathrm{~T}$ & $\mathrm{~T}$ & $\mathrm{G}$ & . & . & . & . & $\mathrm{A}$ & . & $\mathrm{C}$ & . & $\mathrm{C}$ & $\mathrm{G}$ & $\mathrm{C}$ & . & . & & & $\mathrm{C}$ & . & & tal 2 & 18 (6) \\
\hline
\end{tabular}

which is found in its most northerly expanse of its range in the summer, might correspond to the Basques' "summer coastal whaling season" (la costera del verano) while the bowhead whale, which is most southerly in the winter, might be that of their "winter coastal whaling season" (la costera del invierno) (Aguilar, 1986; Cumbaa, 1986). 
However, to date there are no direct data or Basque records to support this.

On the basis of the results presented here, which show no evidence of a right whale-targeted hunt, we suggest that the two distinct summer and winter whaling seasons of the Basques may have represented particular sex or age classes of bowheads with differing migration patterns. Bowhead whales are known to migrate and segregate at particular times of the year by distinct "classes" often based on age and sex (e.g., Brown, 1868; Southwell, 1898; Cubbage and Calambokidis, 1987; Finley, 1990; Moore and Reeves, 1993). Sometimes distinct behavioural traits (such as those of "rocknose" whales: Southwell, 1898; Finley, 1990), migratory patterns, and habitat choices (such as open water vs. ice edge) are associated with particular groups of whales (e.g., Southwell, 1898; Reeves et al., 1983; Finley, 1990; Würsig and Clark, 1993; Cosens and Blouw, 2003). These characteristics were so evident to whalers in earlier centuries that bowheads were described as being composed of distinct "tribes" (Scoresby, 1820; Southwell, 1898). Potentially, the groups of whales migrating to the Strait of Belle Isle that were hunted by the Basques were distinct classes with differing migratory patterns. Thus, the catch may have represented (like most whaling) a non-random removal of particular groups within the historical population. Again, it is not known how the climatic effects of the Little Ice Age may have affected the timing of migration and distribution of either species.

It has been suggested that bones remaining from the whales hunted during the summer whaling season (a seasonal hunt that had largely been abandoned by the mid 1570s) might be found at greater soil depths than those of whales hunted in the years that followed (during the winter whaling season). Under this proposition, if the whale hunted during the summer season was a different species than the whale hunted during the winter season, bones remaining from this species might be found at greater archaeological depths and would not be found when sampling at the soil surface. However, at the one place where strata were extensively searched (Red Bay), there is no evidence of any existing strata relating to species. Our sample set encompasses 85 whale bones from the $104 \mathrm{~m}^{2}$ marine excavation of the sunken galleon (Grenier et al., 2007), an excavation spanning from pre-Basque to post-Basque deposits, and only a single right whale bone has been identified. This specimen was recovered from post- 1565 deposits. Further research on possible strata is recommended.

The identification of such a large number of 16th- to 17 th-century bowhead specimens represents a rare opportunity to investigate historical genetic diversity and the effects of whaling activities on genetic diversity in such a long-lived species. Our calculated values of withinspecies (0.0006) and between-species (0.038) distances are in concordance with expected levels of genetic divergence of the cytochrome $b$ gene in mammalian species (e.g., Johns and Avise, 1998). However, although this is one of the most widely sequenced genes in vertebrates, there is a lack of information (for any mammalian species) on measures of variation within species such as nucleotide polymorphism, nucleotide diversity, and haplotype diversity. To further evaluate temporal variation in genetic diversity and to make inferences on historical population sizes, we have now analyzed the mitochondrial control region and a number of nuclear microsatellite loci (B. McLeod, unpubl. data).

\section{CONCLUSION}

The results presented here provide strong evidence that the bowhead whale was the principal target of 16th- to 17th-century Basque whaling in the western North Atlantic. Thus the impact of this whaling on the bowhead whale population in the Arctic waters adjacent to the northwest Atlantic was much greater than previously recognized, with the majority of an estimated 25000-40000 whales killed being bowhead whales. Although this is a crude estimate of the whales killed during this $\sim 80$ year period, it is roughly equivalent to (if not greater than) the number of whales killed from the Davis Strait population in the centuries of pelagic whaling that followed (1719-1915; $\mathrm{n}=\sim 28$ 000) (Ross, 1993). Clearly, the pre-exploitation population size of the Hudson Bay/Davis Strait population(s) of this species was much larger than has been estimated previously.

Conversely, our results suggest that the right whale did not comprise $50 \%$ of an estimated 25000-40000 Basque kills between 1530 and 1610 (Aguilar, 1986), and instead represented a very small proportion of the whales hunted. Therefore, the pre-exploitation population size of this species was much smaller than has been previously estimated (10000-15000) (Gaskin, 1991; NMFS, 1991), and likely was similar to the population size of the mid-1600s of at least a few thousand whales in the western North Atlantic (Reeves et al., 2007). This altered view of the history of the North Atlantic right whale is important because these estimates of pre-exploitation population size and number of whales killed are frequently used to evaluate recovery (e.g., Greene et al., 2003).

\section{ACKNOWLEDGEMENTS}

Financial support for this work was provided by the Canadian Whale Institute, the Northern Scientific Training Program (NSTP), the Department of Fisheries and Oceans Science Subvention program, the Ocean Life Institute (Woods Hole Oceanographic Institution), and the Natural Sciences and Engineering Research Council of Canada (NSERC). Overhead and logistic support was provided by the Natural Resources DNA Profiling and Forensic Centre (NRDPFC), the New England Aquarium (NEAQ), the Wood's Hole Oceanographic Institution (WHOI) and the Battle Harbour Historic Trust. We would like to acknowledge three anonymous reviewers, T.R. Frasier, and R.R. Reeves, whose 
comments improved both the quality and clarity of this manuscript. Sampling in Labrador and Quebec was conducted under permits issued by the Provincial Museum of Newfoundland and Labrador and by the Ministère de la Culture et des Communications, Quebec, and with additional permission from the Parks Canada Red Bay National Historic Site, P. St-Amand (Parc de l'aventure basque en Amérique), M. Thomas (Whiteley Museum, Riviere St. Paul, QC), and W. Fitzhugh (Smithsonian Institution). We extend our appreciation to the following people for their assistance: J. Lien, W. Ledwell, and M. Sheridan (Memorial University); C. Gibbons, P. Waddell, R. Harris, C. Ludin, and Y. Troutett (Parks Canada); L. Turgeon (Laval University); P. Drouin (Parcs Canada, Centre de services du Québec); D. Sanford; W. Evans; C. Vatcher; T. Frasier; B. Reeves; A. Budden; B. Lentell; Y. Chretien, and A. Herzog (Centre de conservation du Québec); A. Evans; the Griffin family; and P. Russell. Special thanks to the Moore family, to the Bridle clan, and to S/V Rosita for our safe passage along the Quebec and Labrador shore.

\section{REFERENCES}

AGUILAR, A. 1986. A review of old Basque whaling and its effect on the right whales (Eubalaena glacialis) of the North Atlantic. Report of the International Whaling Commission, Special Issue 10:191- 199 .

ARNASON, U., and GULLBERG, A. 1993. Comparison between the complete mtDNA sequences of the blue and the fin whale, two species that can hybridize in nature. Journal of Molecular Evolution 37(4):312-322.

—_. 1994. Relationship of baleen whales established by cytochrome $b$ gene sequence comparison. Nature 367(6465): $726-728$.

ARNASON, U., GULLBERG, A., and WIDEGREN, B. 1991. The complete nucleotide sequence of the mitochondrial DNA of the fin whale, Balaenoptera physalus. Journal of Molecular Evolution 33(6):556-568.

ARNASON, U., GULlbERG, A., and JANKE, A. 2004. Mitogenomic analyses provide new insights into cetacean origin and evolution. Gene 333:27-34.

AUGER, R., FITZGERALD, W., and TURGEON, L. 1992. Fouilles archéologiques et reconnaissances à l'Île aux Basques (DaEh-1, DaEh-4, DaEh-6, DaEh-7). Unpubl. ms. Available at Québec, CELAT, Pavillon Charles-De Koninck, bur. 5173, Université Laval, Québec, Québec G1K 7P4.

_. 1993. Île aux Basques 1992: Fouilles archéologiques au site Cache (DaEh-1) et au site Hoyarsabal (DaEh-4). Unpubl. ms. Available at Québec, CELAT, Pavillon Charles-De Koninck, bur. 5173, Université Laval, Québec, Québec G1K 7P4.

AZKARATE, A., HERNANDEZ, J.A., and NUNEZ, J. 1992. Balleneros vascos del siglo XVI: Estudio arqueológico y contexto histórico, Chateau Bay, Labrador, Canada. Vitoria-Gasteiz: Servicio Central de Publicaciones del Gobierno Vasco. 261 p.

BARKHAM, M. 1991. Shipowning, shipbuilding, and trans-Atlantic fishing in Spanish Basque ports, 1560-1630: A case study of Motrico and Zumaya. PhD thesis, Cambridge University, Cambridge, United Kingdom. 336 p.
BARKHAM, S.H. 1977. The identification of Labrador ports in Spanish 16th-century documents. Cartographica 14:1-9. 1978. The Basques: Filling a gap in our history between Jacques Cartier and Champlain. Canadian Geographic 96:8-19. 1980. A note on the Strait of Belle Isle during the period of Basque contact with Indians and Inuit. Inuit Studies 4:51-58.

. 1984. The Basque whaling establishments in Labrador 1536-1632-A summary. Arctic 37(4):515-519.

BARNES, I., MATHEUS, P., SHAPIRO, B., JENSEN, D., and COOPER, A. 2002. Dynamics of Pleistocene population extinctions in Beringian brown bears. Science 295:2267-2270.

BARNOSKY, A.D., HADLY, E.A., and BELL, C.J. 2003. Mammalian response to global warming on varied temporal scales. Journal of Mammalogy 84(2):354-368.

BORGE, T., BACHMANN, L., BJORNSTAD, G., and WIIG, $\varnothing$. 2007. Genetic variation in Holocene bowhead whales from Svalbard. Molecular Ecology 16(11):2223-2235.

BOUZAT, J.L. 2001. The importance of control populations for the identification and management of genetic diversity. Genetica 110:109-115.

BOUZAT, J.L., LEWIN, H.A., and PAIGE, K.N. 1998. The ghost of genetic diversity past: Historical DNA analysis of the greater prairie chicken. The American Naturalist 152(1):1-6.

BROWN, R. 1868. Notes on the history and geographical relations of the Cetacea frequenting Davis Strait and Baffin's Bay. Proceedings of the Zoological Society of London 1868: 533-556.

CAMERON, A.W. 1951. Greenland right whale recorded in Gaspé County, Quebec. National Museum of Canada Bulletin 123: $116-119$.

CHAN, Y.L., LACEY, E.A., PEARSON, O.P., and HADLY, E.A. 2005. Ancient DNA reveals Holocene loss of genetic diversity in a South American rodent. Biology Letters 1(4):423-426.

CLAPHAM, P.J., YOUNG, S.B., and BROWNELL, R.L., Jr. 1999. Baleen whales: Conservation issues and the status of most endangered whale populations. Mammal Review 29(1):35-60.

COSENS, S.E., and BLOUW, A. 2003. Size- and age-class segregation of bowhead whales summering in northern Foxe Basin: A photogrammetric analysis. Marine Mammal Science 19(2):284-296.

CUBBAGE, J.C., and CALAMBOKIDIS, J. 1987. Size-class segregation of bowhead whales discerned through aerial stereophotogrammetry. Marine Mammal Science 3(2): $179-185$.

CUMBAA, S.L. 1986. Archaeological evidence of the 16th century Basque right whale fishery in Labrador. Report of the International Whaling Commission, Special Issue 10:187-190.

DE JONG, C. 1983. The hunt of the Greenland whale: A short history and statistical sources. Report of the International Whaling Commission, Special Issue 5:83-106.

DROUIN, P. 1988. Les baleiniers basques à l'Île Nue de Mingan. Canadian Journal of Archaeology 12:1-15.

EASTOP, D., and McEWING, R. 2004. Informing textile and wildlife conservation: DNA analysis of baleen from an 18thcentury garment found deliberately concealed in a building. In: Wyeth, P., and Janaway, R., eds. Scientific analysis of ancient and historic textiles: Informing preservation, display and 
interpretation: Postprints of the First Conference of the AHRB Research Centre for Textile Conservation and Textile Studies, 13-15 July 2004, London, Archetype. 161-167.

ESCHRICHT, D.F., and REINHARDT, J. 1866. On the Greenland right-whale (Balaena mysticetus, Linn.), with especial reference to its geographical distribution and migrations in times past and present and to its external and internal characteristics. In: Flower, W.H., ed. Recent memoirs on the Cetacea by Professors Eschricht, Reinhardt and Lilljeborg. Piccadilly, London: Ray Society. $1-150$.

FINLEY, K.J. 1990. Isabella Bay, Baffin Island: An important historical and present-day concentration area for the endangered bowhead whale (Balaena mysticetus) of the eastern Canadian Arctic. Arctic 43(2):137-152.

FITZGERALD, W., DE VARENNES, P., and TURGEON, L. 1997. Basques et Amérindiens à l'île aux Basques aux XVIe et XVIIe siècles: Intervention archéologique du 1993. Unpubl. ms. Available at Québec, CELAT Pavillon Charles-De Koninck, bur. 5173, Université Laval, Québec, Québec G1K 7P4.

FITZHUGH, W.W. 2001. The Gateways Project 2001: Archaeological survey of the Quebec lower north shore, Gulf of St. Lawrence, from Mingan to Blanc Sablon. Unpubl. ms. Available at the Arctic Studies Center, Department of Anthropology, National Museum of Natural History, Smithsonian Institution, P.O. Box 37012, Washington D.C. 20013-0112. $90 \mathrm{p}$.

FITZHUGH, W.W., and GALLON, M. 2002. The Gateways Project 2002: Surveys and excavations from Petit Mécatina to Belles Amours. Unpubl. ms. Available at the Arctic Studies Center, Department of Anthropology, National Museum of Natural History, Smithsonian Institution, P.O. Box 37012, Washington, D.C. 20013-0112. 174 p.

FITZHUGH, W.W., and SHARP, H. 2003. The Gateways Project 2003: Surveys and excavations from Hare Harbour to Jacques Cartier Bay. Unpubl. ms. Available at the Arctic Studies Center, Department of Anthropology, National Museum of Natural History, Smithsonian Institution, P.O. Box 37012, Washington, D.C. 20013-0112. 190 p.

FITZHUGH, W.W., CHRETIEN, Y., and SHARP, H. 2004. The Gateways Project 2004: Surveys and excavations from Chevery to Jacques Cartier Bay. Unpubl. ms. Available at the Arctic Studies Center, Department of Anthropology, National Museum of Natural History, Smithsonian Institution, P.O. Box 37012, Washington, D.C. 20013-0112. 114 p.

FITZHUGH, W.W., CHRETIEN, Y.,PHANNEUF, E., and SHARP, H. 2006. The Gateways Project 2005: Surveys and excavations from Mutton Bay to Harrington Harbour. Unpubl. ms. Available at the Arctic Studies Center, Department of Anthropology, National Museum of Natural History, Smithsonian Institution, P.O. Box 37012, Washington, D.C. 20013-0112. 56 p.

GASKIN, D.E. 1991. An update on the status of the right whale, Eubalaena glacialis, in Canada. Canadian Field-Naturalist 105:198-205.

GEORGE, J.C., ZEH, J., SUYDAM, R., and CLARK, C. 2004. Abundance and population trend (1978-2001) of western Arctic bowhead whales surveyed near Barrow, Alaska. Marine Mammal Science 20(4):755-773.
GOLDSTEIN, P.Z., and DESALLE, R. 2003. Calibrating phylogenetic species formation in a threatened insect using DNA from historical specimens. Molecular Ecology 12:1993-1998.

GREENE, C.H., and PERSHING, A.J. 2004. Climate and the conservation biology of North Atlantic right whales: The right whale at the wrong time? Frontiers in Ecology and the Environment 2(1):29-34.

GREENE, C.H., PERSHING, A.J., KENNEY, R.D., and JOSSI, J.W. 2003. Impact of climate variability on the recovery of endangered North Atlantic right whales. Oceanography 16(4): $98-103$.

GRENIER, R. 1985. Excavating a 400-year-old Basque galleon. National Geographic 168.1:58-68.

GRENIER, R., BERNIER, M., and STEVENS, W., eds. 2007. The underwater archaeology of Red Bay: Basque shipbuilding and whaling in the 16th century. 5 vols. Ottawa: Parks Canada.

GROOMBRIDGE, J.J., JONES, C.G., BRUFORD, M.W., and NICHOLS, R.A. 2000. 'Ghost' alleles of the Mauritius kestrel. Nature 403:616.

HADLY, E.A., KOHN, M.H., LEONARD, J.A., and WAYNE, R.K. 1998. A genetic record of population isolation in pocket gophers during Holocene climatic change. Proceedings of the Royal Academy of Sciences 95:6893-6896.

HADLY, E.A., VAN TUINEN, M., CHAN, Y., and HEIMAN, K. 2003. Ancient DNA evidence of prolonged population persistence with negligible genetic diversity in an endemic Tuco-Tuco (Ctenomys sociabilis). Journal of Mammalogy 84(2):403-417.

HARINGTON, C.R. 1977. Marine mammals in the Champlain Sea and the great lakes. Annals of the New York Academy of Sciences 288:508-537.

HEIDE-JØRGENSEN, M.P., LAIDRE, K.L., JENSEN, M.V., DUECK, L., and POSTMA, L.D. 2006. Dissolving stock discreteness with satellite tracking: Bowhead whales in Baffin Bay. Marine Mammal Science 22(1):34-45.

HENSHAW, A. 2003. Polynyas and ice edge habitats in cultural context: Archaeological perspectives from southeast Baffin Island. Arctic 56(1):1-13.

HUXLEY [BARKHAM], S. 1987. Los vascos y las pesquerías transatlánticas, 1517-1713. In: Huxley, S., ed. Itsasoa 3: Los vascos en el marco Atlántico Norte. Siglos XVI y XVII. San Sebastián: Editorial Etor. 26-210.

IWC (INTERNATIONAL WHALING COMMISSION). 2001. Report on the workshop on the comprehensive assessment of right whales: A worldwide comparison. Journal of Cetacean Research and Management, Special Issue 2:1-60.

IUCN (THE WORLD CONSERVATION UNION). 2006. 2006 IUCN red list of threatened species. <Www.iucnredlist.org>.

JACOBSEN, K., MARX, M., and ØIEN, N. 2004. Two-way transAtlantic migration of a North Atlantic right whale (Eubalaena glacialis). Marine Mammal Science 20(1):161-166.

JOHNS, G.C., and AVISE, J.C. 1998. A comparative summary of genetic distances in the vertebrates from the mitochondrial cytochrome $b$ gene. Molecular Biology and Evolution 15(11):1481-1490.

KNOWLTON, A.R., KRAUS, S.D., and KENNEY, R.D. 1994. Reproduction in North Atlantic right whales (Eubalaena glacialis). Canadian Journal of Zoology 72(7):297-305. 
KNOWLTON, A.R., SIGURJONSSON, J., CIANO, J.N., and KRAUS, S.D. 1992. Long-distance movements of North Atlantic right whales (Eubalaena glacialis). Marine Mammal Science 8(4):397-405.

KRAUS, S.D., HAMILTON, P.K., KENNEY, R.D., KNOWLTON, A.R., and SLAY, C.K. 2001. Reproductive parameters of the North Atlantic right whale. Journal of Cetacean Research and Management, Special Issue 2:231-236.

KRAUS, S.D., BROWN, M.W., CASWELL, H., CLARK, C.W., FUJIWARA, M., HAMILTON, P.K., KENNEY, R.D., KNOWLTON, A.R., LANDRY, S., MAYO, C.A., McLELLAN, W.A., MOORE, M.J., NOWACEK, D.P., PABST, D.A., READ, A.J., and ROLLAND, R.M. 2005. North Atlantic right whales in crisis. Science 309:561-562.

KRAUSE, J., DEAR, P.H., POLLACK, J.L., SLATKIN, M., SPRIGGS, H., BARNES, I., LISTER, A.M., EBERSBERGER, I., PAABO, S., and HOFREITER, M. 2006. Multiplex amplification of the mammoth genome and the evolution of Eliphantidae. Nature 439:724-727.

KREUTZ, K.J., MAYEWSKI, P.A., MEEKER, L.D., TWICKLER, M.S., WHITLOW, S.I., and PITTALWALA, I.I. 1997. Bipolar changes in atmospheric circulation during the Little Ice Age. Science 277:1294-1296.

KUMAR, S., TAMURA, K., and NEI, M. 2004. MEGA3: Integrated software for molecular evolutionary genetics analysis and sequence alignment. Briefing in Bioinformatics 5:150-163.

LALANDE, D. 1989a. Fouilles archéologiques du site historique de Bon Désir (DbEi-5) et bilan des activités. Unpubl. ms. Available at Québec, CELAT, Pavillon Charles-De Koninck, bur. 5173, Université Laval, Québec, Québec G1K 7P4.

. 1989b. Archeological excavations at Bon-Désir: Basque presence in the St. Lawrence Estuary. Northeastern Historical Archaeology 18:10-28.

- 1990. Fouilles archéologiques du site historique de Bon Désir (DbEi-5) et bilan des activités. Unpubl. ms. Available at Québec, CELAT, Pavillon Charles-De Koninck, bur. 5173, Université Laval, Québec, Québec G1K 7P4.

. 1991. Fouilles archéologiques du site historique de l'île aux Basques (DaEh-4 et DaEh-5). Unpubl. ms. Available at Québec, CELAT, Pavillon Charles-De Koninck, bur. 5173, Université Laval, Québec, Québec G1K 7P4.

LAMB, H.H. 1995. Climate, history and the modern world, 2nd ed. New York: Routledge. 464 p.

LAMBERT, D.M., RITCHIE, P.A., MILLAR, C.D., HOLLAND, B., DRUMMOND, A.J., and BARONI, C. 2002. Rates of evolution in ancient DNA from Adélie penguins. Science 295:2270-2273.

LARSON, S., JAMESON, R., ETNIER, M., FLEMING, M., and BENTZEN, P. 2002. Loss of genetic diversity in sea otters (Enhydra lutris) associated with the fur trade of the 18th and 19th centuries. Molecular Ecology 11:1899-1903.

LEDUC, R.G., PERRIN, W.F., and DIZON, A.E. 1999. Phylogenetic relationships among the delphinid cetaceans based on full cytochrome $b$ sequences. Marine Mammal Science 15(3): 619-648.

LEDWELL, W., BENJAMINS, S., LAWSON, J., and HUNTINGTON, J. 2007. The most southerly record of a stranded bowhead whale, Balaena mysticetus, from the western North Atlantic Ocean. Arctic 60(1):17-22.

LEONARD, J.A., WAYNE, R.K., and COOPER, A. 2000. Population genetics of ice age brown bears. Proceedings of the National Academy of Sciences of the United States of America 97(4): $1651-1654$.

MALIK, S., BROWN, M.W., KRAUS, S.D., and WHITE, B.N. 2000. Analysis of mitochondrial DNA diversity within and between North and South Atlantic right whales. Marine Mammal Science 16(3):545-558.

MARTIN, A.R., and WALKER, F.J. 1997. Sighting of a right whale (Eubalaena glacialis) with calf off S.W. Portugal. Marine Mammal Science 13(10):139-140.

MATOCQ, M.D., and VILLABLANCA, F.X. 2001. Low genetic diversity in an endangered species: Recent or historic pattern? Biological Conservation 98:61-68.

McGHEE, R. 1969/70. Speculations on climatic change and Thule culture development. Folk 11-12:173-184.

MOORE, S.E., and REEVES, R.R. 1993. Distribution and movement. In: Burns J.J., Montague, J.J., and Cowles, C.J., eds. The bowhead whale. Society for Marine Mammalogy, Special Publication No. 2. Lawrence, Kansas: Allen Press Inc. 313-386.

MOORE, S.E., DeMASTER, D.P., and DAYTON, P.K. 2000. Cetacean habitat selection in the Alaskan Arctic during summer and autumn. Arctic 53(4):432 - 447.

MORIN, P.A., LEDUC, R.G., ROBERTSON, K.M., HEDRICK, N.M., PERRIN, W.F., ETNIER, M., and TAYLOR, B.L. 2006. Genetic analysis of killer whale (Orcinus orca) historical bone and tooth samples to identify western U.S. ecotypes. Marine Mammal Science 22(4):897-909.

MOSHENKO, R.W., COSENS, S.E., and THOMAS, T.A. 2003. Conservation strategy for bowhead whales (Balaena mysticetus) in the eastern Canadian Arctic. National Recovery Plan No. 24. Ottawa, Ontario: Recovery of Nationally Endangered Wildlife (RENEW). $51 \mathrm{p}$.

NMFS (NATIONAL MARINE FISHERIES SERVICE). 1991. Final recovery plan for the northern right whale Eubalaena glacialis. Silver Spring, Maryland: U.S. Department of Commerce, National Oceanic and Atmospheric Administration, National Marine Fisheries Service, Office of Protected Resources. 86 p.

NEI, M. 1987. Molecular evolutionary genetics. New York: Columbia University Press.

NIELLON, F. 1986. Intervention archéologique sur les sites historiques de la baie des Cinq Lieues et de la baie di Milieu, Basse Côte-Nord, Québec. Report submitted to the Ministry of Cultural Affairs, Québec. Available from Ministère de la Culture, des Communications et de la Condition feminine, 225, Grande Allée est, Québec, Québec G1R 5G5. 19-26.

NIELLON, F., and McGAIN, A. 1987. La station baleinière basque de la baie du Milieu: Recherche archéologique 1987 sur le site EiBi-10. Report submitted to the Ministry of Cultural Affairs, Québec. Available from Ministère de la Culture, des Communications et de la Condition feminine, 225, Grande Allée est, Québec, Québec G1R 5G5. 69 p.

NYSTROM, V., ANGERBÖRN, A., and DALEN, L. 2006. Genetic consequences of a demographic bottleneck in the Scandanavian arctic fox. Oikos 114(1):84-94. 
ORLANDO, L., BONJEAN, D., BOCHERENS, H., THENOT, A., ARGANT, A., OTTE, M., and HANNI, C. 2002. Ancient DNA and the population genetics of cave bears (Ursus spelaeus) through space and time. Molecular Biology and Evolution 19(11):1920-1933.

PALO, J.U., HYVARINEN, H., HELLE, E., MAKINEN, H.S., and VAINOLA, R. 2003. Postglacial loss of microsatellite variation in the landlocked Lake Saimaa ringed seal. Conservation Genetics 4:117-128.

PAXINOS, E.E., JAMES, H.F., OLSON, S.L., BALLOU, J.D., LEONARD, J.A., and FLEISCHER, R.C. 2002. Prehistoric diversity of genetic diversity in the Nene. Science 296:1827.

PERTOLDI, C., HANSEN, M.M., LOESCHCKE, V., MADSEN, A.B., JACOBSEN, L., and BAAGOE, H. 2001. Genetic consequences of population decline in the European otter (Lutra lutra): An assessment of microsatellite DNA variation in Danish otters from 1883 to 1993 . Proceedings of the Royal Society of London, Series B 268:1775-1781.

PICHLER, F.B., DALEBOUT, M.L., and BAKER, C.S. 2001. Nondestructive DNA extraction from sperm whale teeth and scrimshaw. Molecular Ecology Notes 1:106-109.

POSADA, D., and CRANDALL, K. 1998. MODELTEST: Testing the model of DNA substitution. Bioinformatics 14(9):817-818.

POULAKAKIS, N., PARMAKELIS, A., LYMBERAKIS, P., MYLONAS, M., ZOUROS, E., REESE, D.S., GLABERMAN, S., and CACCONE, A. 2006. Ancient DNA forces reconsideration of evolutionary history of Mediterranean elephantids. Biology Letters 2(3):451-454.

RASTOGI, T., BROWN, M.W., McLEOD, B.A., FRASIER, T.R., GRENIER, R., CUMBAA, S.L., NADARAJAH, J., and WHITE, B.N. 2004. Genetic analysis of 16th-century whale bones prompts a revision of the impact of Basque whaling on right and bowhead whales in the western North Atlantic. Canadian Journal of Zoology 82:1647-1654.

REEVES, R.R. 2001. Overview of catch history, abundance and distribution of right whales in the western North Atlantic and in Cintra Bay, West Africa. Journal of Cetacean Research and Management, Special Issue 2:187-192.

REEVES, R.R., and MITCHELL, E. 1986. American pelagic whaling for right whales in the North Atlantic. Report of the International Whaling Commission, Special Issue 10:221 - 254.

REEVES, R.R., and SMITH, T.D. 2006. A taxonomy of world whaling: Operations and eras. In: Estes, J.A., DeMaster, D.P., Doak, D.F., Williams, T.M., and Brownell, R.L., Jr., eds. Whales, whaling, and ocean ecosystems. Berkeley: University of California Press. 82-101.

REEVES, R.R., MITCHELl, E., MANSFIELD, A., and McLAUGHLIN, M. 1983. Distribution and migration of the bowhead whale, Balaena mysticetus, in the eastern North American Arctic. Arctic 36(1):5-64.

REEVES, R.R., SMITH, T.D., and JOSEPHSON, E. 2007. Near annihilation of a species: Right whaling in the North Atlantic. In: Kraus, S.D., and Rolland, R.M., eds. The urban whale: North Atlantic right whales at the crossroads. Cambridge, Massachusetts: Harvard University Press. 39-74.

ROSENBAUM, H.C., EGAN, M.G., CLAPHAM, P.J., BROWNELL, R.L., Jr., and DESALLE, R. 1997. An effective method for isolating DNA from historical specimens of baleen. Molecular Ecology 6:677-681.

ROSS, W.G. 1993. Commercial whaling in the North Atlantic sector. In: Burns, J.J., Montague, J.J., and Cowles, C.J., eds. The bowhead whale. Society for Marine Mammalogy, Special Publication No. 2. Lawrence, Kansas: Allen Press Inc. 511-561.

ROZAS, J., SANCHEZ-DELBARRIO, J.C., MESSEGUER, X., and ROZAS, R. 2003. DnaSP, DNA polymorphism analyses by the coalescent and other methods. Bioinformatics 19(18): 2496-2497.

RYCHEL, A.L., REEDER, T.W., and BERTA, A. 2004. Phylogeny of mysticete whales based on mitcochondrial and nuclear data. Molecular Phylogenetics and Evolution 32(3):892-901.

SASAKI, T., NIKAIDO, M., HAMILTON, H., GOTO, M., KATO, H., KANDA, N., PASTENE, L.A., CAO, Y., FORDYCE, R.E., HASAGAWA, M., and OKADA, N. 2005. Mitochondrial phylogenetics and evolution of mysticete whales. Sytematic Biology 54(1):77-90.

SASAKI, T., NIKAIDO, M., WADA, S., YAMADA, T.K., CAO, Y., HASAGAWA, M., and OKADA, N. 2006. Balaenoptera omurai is a newly discovered baleen whale that represents an ancient evolutionary lineage. Molecular Phylogenetics and Evolution 41(1):40-52.

SCHAEFF, C., KRAUS, S., BROWN, M., GASKIN, D., BOAG, P., and WHITE, B. 1991. Preliminary analysis of mitochondrial DNA variation within and between the right whale species Eubalaena glacialis and Eubalaena australis. Report of the International Whaling Commission, Special Issue 13:217-223.

SCHAEFF, C.M., KRAUS, S.D., BROWN, M.W., PERKINS, J.S., PAYNE, R., and WHITE, B.N. 1997. Comparison of genetic variability of North and South Atlantic right whales (Eubalaena), using DNA fingerprinting. Canadian Journal of Zoology 75:1073-1080.

SCHLEDERMANN, P. 1976. The effect of climatic/ecological changes on the style of Thule culture winter dwellings. Arctic and Alpine Research 8(1):37-47.

SCHMIDT, H.A., STRIMMER, K., VINGRON, M., and VON HAESELER, A. 2002. TREE-PUZZLE: Maximum likelihood phylogenetic analysis using quartets and parallel computing. Bioinformatics 18:502-504.

SCORESBY, W. 1820. An account of the Arctic regions, with a history and description of the northern whale-fishery. Edinburgh: Archibald Constable and Co. 2 vols. 551 p. and 524 p.

SHAPIRO, B., DRUMMOND, A.J., RAMBAUT, A., WILSON, M.C., MATHEUS, P.E., SHER, A.V., PYBUS, O.G., GILBERT, M.T.P., BARNES, I., BINLADEN, J., WILLERSLEV, E., HANSEN, A.J., BARYSHNIKOV, G.F., BURNS, J.A., DAVYDOV, S., DRIVER, J.C., FROESE, D.G., HARINGTON, C.R., KEDDIE, G., KOSINTSEV, P., KUNZ, M.L., MARTIN, L.D., STEPHENSON, R.O., STORER, J., TEDFORD, R., ZIMOV, S., and COOPER, A. 2004. Rise and fall of the Beringian steppe bison. Science 306:1561-1565.

SOUTHWELL, T. 1898. The migration of the right whale (Balaena mysticetus). Natural Science 12:397-414.

SPRINGER, A.M., ESTES, J.A., VAN VLIET, G.B., WILLIAMS, T.M., DOAK, D.F., DANNER, E.M., FORNEY, K.A., and PFISTER, B. 2003. Sequential megafaunal collapse in the North 
Pacific Ocean: An ongoing legacy of industrial whaling? Proceeding of the National Academy of Sciences of the USA 100:12223-12228.

STOKER, S.W., and KRUPNIK, I.I. 1993. Subsistence whaling. In: Burns, J.J., Montague, J.J., and Cowles, C.J., eds. The bowhead whale. Society for Marine Mammalogy, Special Publication No. 2. Lawrence, Kansas: Allen Press Inc. 579629.

STOPP, M.P. 1997. Long-term coastal occupancy between Cape Charles and Trunmore Bay, Labrador. Arctic 50(2):119-137.

STRIMMER, K., and VON HAESELER, A. 1996. Quartet puzzling: A quartet maximum likelihood method for reconstructing tree topologies. Molecular Biology and Evolution 13:964-969.

TAMURA, T., and NEI, M. 1993. Estimation of the number of nucleotide substitutions in the control region of mitochondrial DNA in humans and chimpanzees. Molecular Biology and Evolution 10(3):512-526.

TEBBUTT, S.J., STEWART, R.E., and HILL, D.F. 2000. Isolation and characterization of DNA from whale bone. Journal of the Royal Society of New Zealand 30(4):365-371.

THOMPSON, J.D., GIBSON, T.J., PLEWNIAK, F., JEANMOUGIN, F., and HIGGENS, D.S. 1997. The CLUSTAL_X windows interface: Flexible strategies for multiple sequence alignment aided by quality analysis tools. Nucleic Acids Research 25(24):4876-4882.

TUCK, J.A. 1985. Unearthing Red Bay's whaling history. National Geographic 168.1:50-57.

TURGEON, L. 1998. French fishers, fur traders, and Amerindians during the sixteenth century: History and archaeology. William and Mary Quarterly 55:585-610.

WADE, P.R., BURKANOV, V.N., DAHLHEIM, M.E., FRIDAY, N.A., FRITZ, L.W., LOUGHLIN, T.R., MIZROCH, S.A., MUTO, M.M., RICE, D.W., BARRETT-LENNARD, L.G.,
BLACK, N.A., BURDIN, A.M., CALAMBOKIDIS, J., CERCHIO, S., FORD, J.K.B., JACOBSEN, J.K., MATKIN, C.O., MATKIN, D.R., MEHTA, A.V., SMALL, R.J., STRALEY, J.M., McCLUSKEY, S.M., VanBLARICOM, G.R., and CLAPHAM, P.J. 2007. Killer whales and marine mammal trends in the North Pacific: A re-examination of evidence for sequential megafauna collapse and the prey-switching hypothesis. Marine Mammal Science 23(4):766-802, doi:10.1111/j.17487692.2006.00093.x.

WALDICK, R.C., KRAUS, S.D., BROWN, M.W., and WHITE, B.N. 2002. Evaluating the effects of historic bottleneck events: An assessment of microsatellite variability in the endangered, North Atlantic right whale. Molecular Ecology 11:2241-2249.

WOODBY, D.A., and BOTKIN, D.B. 1993. Stock sizes prior to commercial whaling. In: Burns, J.J., Montague, J.J., and Cowles, C.J., eds. The bowhead whale. Society for Marine Mammalogy, Special Publication No. 2. Lawrence, Kansas: Allen Press Inc. 387-407.

WURSIG, B., and CLARK, C. 1993. Behaviour. In: Burns, J.J., Montague, J.J., and Cowles, C.J., eds. The bowhead whale. Society for Marine Mammalogy, Special Publication No. 2. Lawrence, Kansas: Allen Press Inc. 157-199.

YANG, Z. 1993. Maximum likelihood estimation of phylogeny from DNA sequences when substitution rates differ over sites. Molecular Biology and Evolution 10(6):1396-1401.

- 1994. Maximum likelihood phylogenetic estimation from DNA sequences with variable rates over sites: Approximate methods. Journal of Molecular Evolution 39:306-314.

ZEH, J.E., CLARK, C.W., GEORGE, J.C., WITHROW, D., CARROLL, G.M., and KOSKI, W.R. 1993. Current population size and dynamics. In: Burns, J.J., Montague, J.J., and Cowles, C.J., eds. The bowhead whale. Society for Marine Mammalogy, Special Publication No. 2. Lawrence, Kansas: Allen Press Inc. 409-489. 